\title{
A Dilution Mechanism for Valuing Corporations in Bankruptcy
}

\author{
Barry E. Adler ${ }^{\dagger}$ and Ian Ayres ${ }^{\dagger \dagger}$
}

\section{CONTENTS}

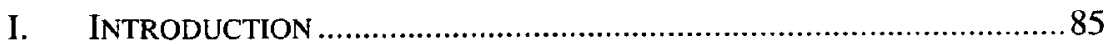

II. ABSOLUTE PRIORITY AND THE ROLE OF MARKETS .........................8 88

A. Absolute Priority .................................................................8 88

B. Market vs. Nonmarket Determination.......................................90

III. THE SIMPLE ECONOMICS OF DILUTION.............................................96

A. Dilution and "Topping-Off" Methods of Valuation ...................96

B. A Numerical Example ......................................................... 100

C. A Formal Two-Player Model ............................................ 106

IV. EXTENDING THE MODEL ............................................................112

A. Adding Players per Class, Classes, and Third-Party Bidders... 112

1. Multiple Players per Class .................................................112

2. Multiple Priority Classes......................................................114

3. Third-Party Bidders ...........................................................116

B. Heterogeneous Valuations ........................................................117

C. Ameliorating the Problem of Junior Illiquidity..........................119

$\dagger$ Professor of Law, New York University School of Law. E-mail: barry.adler@nyu.edu.

†† William K. Townsend Professor, Yale Law School. E-mail: ian.ayres@yale.edu.

This Article is deeply influenced by the fine prior work of Robert M. Daines \& Jon D. Hanson, The Corporate Law Paradox: The Case for Restructuring Corporate Law, 102 YALE L.J. 577 (1992) (reviewing Frank H. EASTERBROOK \& DANIEL R. FISCHEL, THE ECONOMIC STRUCTURE OF CORPORATE LAW (1991)), and Lucian Arye Bebchuk, A New Approach to Corporate Reorganizations, 101 HARV. L. REV. 775 (1988). Indeed, because one of our central goals is to improve upon Bebchuk, the title can also be read as a homonym-a De-Lucian model. Jennifer Arlen, Lucian Bebchuk, John Coates, Richard Friedman, Stuart Gilson, Marcel Kahan, Al Klevorick, Roberta Romano, Alan Schwartz, David Skeel, Eric Talley, Elizabeth Warren, Mark Weinstein, Fred Vars, and seminar participants at Fordham University, the National Bureau of Economic Research, New York University, University of Connecticut, University of Michigan, University of Pennsylvania, and University of Southem California provided helpful comments. 
1. Third-Party Bidding ............................................... 120

2. Leveraging Dilution Shares........................................... 120

3. Free-Riding .............................................................. 124

4. Acquiescence .......................................................... 128

V. APPlying THE "Junior Dilution" APPROACH IN CRAMdOWNS.. 131

A. Inside-Bidders Application .................................................. 134

B. Third-Party Bidders Application ........................................ 138

VI. COMPARISON WITH ALTERNATIVE PROPOSALS .......................... 140

A. Thick External Markets...................................................... 142

B. Thin External Markets ................................................... 146

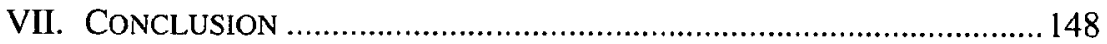




\section{INTRODUCTION}

Issues of corporate finance become most critical when a firm encounters financial distress. In this case, there may be insufficient assets to go around, and the question of valuation comes to the fore. Valuation is central to the resolution of distress because distributions consistent with the hierarchy of investor priority (called "absolute priority") depend on the amount available to distribute. A firm with little value may belong entirely to its most senior creditors, while a firm with much value may belong in part to its junior creditors, or perhaps even its shareholders. Not surprisingly, therefore, valuation is the most hotly contested and debated topic in the realm of corporate bankruptcy law. In this Article, we enter this debate with a new "dilution" approach for valuation. The dilution approach begins with the issuance of some new shares to investors at a particular level of priority, and then, to the extent that absolute priority requires, "dilutes" the value of those shares with the issuance of additional shares, or new claims against the firm, to investors at a different level of priority. This process, which is implemented through a stylized auction at a fixed price, not quantity, harnesses information available among a corporation's investors and the capital market as a whole in order to implement better the absolute priority rule.

Under what we call a "senior dilution" mechanism, a court would dilute the reorganized stock issued to senior claimants by issuing additional shares to junior claimants until there was no excess demand for the senior claimants' stock at a fixed price that would implement absolute priority. For example, imagine a firm with two priority classes of unsecured claimantssenior and junior. At the time of bankruptcy, each is nominally owed $\$ 100$. Under our senior dilution mechanism, a court would issue 100 shares in the reorganized firm to senior claimants but would potentially dilute the value of the seniors' claims by issuing dilution shares to juniors until there was greater supply of seniors' stock than demand at a fixed price of $\$ 1$ per share. If the reorganized firm is worth less than $\$ 100$, there would never be excess demand for senior claimants' stock: Junior claimants or third parties would not want to spend $\$ 1$ to purchase stock worth less than $\$ 1$. Consequently, no dilution shares would be issued to juniors. If, however, the reorganized firm were worth more than $\$ 100$, then junior and thirdparty bidders would have an incentive to offer to buy senior shares until the amount of dilution was sufficient to implement absolute priority. While we leave until later a detailed discussion of the implementation of this fixedprice auction (through a court's solicitation of bidding schedules), ${ }^{1}$ the big

1. See infra Section III.B. 
idea is that senior dilution harnesses the claimants' (and third party bidders') private information to implement absolute priority. When the reorganized firm is worth less than the amount of the senior debt, the senior claimants come away owning all the firm. When the reorganized firm is worth more than the senior debt, the senior claimants come away with assets worth the amount of their debt with the residual going to junior claimants.

The dilution approach, moreover, is not merely a new entry in an academic debate. In the recently decided Bank of America National Trust \& Savings Ass'n v. 203 North LaSalle Street Partnership, ${ }^{2}$ the Supreme Court expressed its dissatisfaction with judicial valuations that allocate interests in corporate debtors over the objection of a class of creditors who argue for a different valuation and thus a different allocation. The Court observed that, when possible within the confines of the bankruptcy reorganization process, bankruptcy judges would do well to resolve valuation disputes through a market mechanism. The difficulty is that traditional market mechanisms do not lend themselves to current American bankruptcy law, which may yield a reorganization plan approved by some but not all classes of creditors. For such a plan, only the noncash property to be received by the dissenters requires valuation, and an auction of that property might or might not yield a price equivalent to the dissenters' priority entitlement. The plan could be scrapped if the auction did not yield the right price, but this would lead proponents to propose a new plan with a different distribution to the dissenters. The result could be a wasteful series of failed plans and attempted sales, perhaps without any successful plan at the end of the process, as it could prove impossible for the proponents to satisfy the dissenters' entitlement consistent with the arrangement made among the other classes.

The dilution approach we propose here solves this problem of an uncertain auction price because, as noted above and explained more fully below, ${ }^{3}$ the dilution mechanism is, in essence, a "fixed-price" auction. To address the claims of a class that dissents from a reorganization plan, we propose a "junior" version of our dilution mechanism. For this version of the mechanism, a price can be fixed at the level of the dissenters' entitlement, and a low-bid auction can be held with bids in the currency of a piece of the debtor to be purchased for that fixed price. The greater the piece required to yield the fixed price, the more diluted the junior's residual interest. When the proponents' reorganization plan can satisfy the dissenters' entitlement, the fixed-price auction will set the distribution accurately. When the plan cannot satisfy the entitlement, the auction will

2. 526 U.S. 434 (1999).

3. See infra Sections III.A-B. 
reveal that fact. There is never a need for multiple plans or auctions. The dilution mechanism, moreover, unlike other market alternatives to judicial valuation, can be employed by the bankruptcy court only when needed to settle a valuation dispute. Absent such a dispute, or until the point of such a dispute, the bankruptcy process can proceed as under current practice. Thus, the dilution mechanism, with its fixed price rather than fixed quantity, is uniquely suitable to provide a market test within current American bankruptcy law. Given the Supreme Court's opinion in LaSalle, this is an opportune moment to propose such a mechanism.

We proceed in steps to build an argument for our dilution mechanism. Part II explains the importance of the absolute priority rule and discusses the relative merits of market as opposed to judicial determination of absolute priority. Part III then explains the fundamentals of our dilution mechanism with an illustration of "senior dilution." Part IV extends the model and includes a description of how the dilution mechanism can mitigate difficulties that arise in any market process when the market in question includes few participants, not all of whom have liquid assets.

Part V shows how American bankruptcy courts could use our dilution mechanism under current law to obtain the benefits of market valuation while preserving the merits of judicially supervised corporate reorganization. This could be accomplished through a "junior dilution" version of our dilution idea. Under this junior dilution mechanism, junior claims would be diluted by giving seniors more claims to the reorganized firm's cash flow until there was no excess supply of senior debt at a fixed price that implements absolute priority. For example, a court might raise the proposed interest rate on senior debt under a proposed reorganization plan until the demand for such debt (from juniors or third parties) was at least as great as the seniors' offers to sell the debt at absolute priority par value. Raising the interest rate would dilute the value of the residual interest left for the junior claims. As with our senior dilution mechanism, we will show that junior dilution is likely to continue until the junior and senior claimants receive their absolute priority just deserts.

Part VI then compares the various implementations of our dilution mechanisms to its three primary market-harnessing competitors: Douglas Baird's auction proposal, ${ }^{4}$ Mark Roe's partial-float proposal, ${ }^{5}$ and Lucian Bebchuk's option proposal. ${ }^{6}$ We devote particular attention to the Bebchuk proposal, which most resembles ours, and which forms a foundation for the dilution mechanism. Our mechanism and the option approach offer similar

4. Douglas G. Baird, Revisiting Auctions in Chapter 11,36 J.L. \& ECON. 633 (1993).

5. Mark J. Roe, Bankruptcy and Debt: A New Model for Corporate Reorganization, 83 COLUM. L. REV. 527 (1983).

6. Lucian Arye Bebchuk, A New Approach to Corporate Reorganizations, 101 HARV. L. REV. 775 (1988). 
advantages over mechanisms based on a full or partial auction of the company. Our mechanism and the option approach also produce similar outcomes in cases where junior claimants have the funds that they might need to exercise the options they would get under the option approach. However, our mechanism could perform better in addressing liquidity problems that junior claimants might face. Part VII offers a conclusion.

\section{ABSOLUTE PRIORITY AND THE ROLE OF MARKETS}

\section{A. Absolute Priority}

It is important to establish why, as a matter of first principles, lawmakers should want to divide the firm according to a strict adherence to priority-called the "absolute priority rule." At the time of investment, those who provide capital to a corporation can anticipate any distribution that occurs after a failure. Based on such anticipation, whatever the ultimate distribution, the investors can adjust the terms on which they provide capital. Therefore, a senior creditor who cannot anticipate strict adherence to absolute priority will charge more for a loan than it would if absolute priority were the rule. With this in mind, one might think it unimportant that distributions strictly follow absolute priority or any particular priority scheme. But absolute priority is important, not because deviations would be unfair to investors, but because such priority, devised by contract, can create efficient investment incentives.

Consider a hypothetically extreme bankruptcy rule, in which all investors-creditors and shareholders alike-are to be paid ratably from the assets of an insolvent firm. Prior to insolvency, managers of a firm subject to such a rule might react with insufficient diligence or excessive risktaking as compared to the effort and risk incentives that would obtain under a rule that pays creditors in full ahead of shareholders. That is, for the managers, anticipation of a soft landing in the event of insolvency would reduce the discipline debt can impose and thus could make failure more likely. ${ }^{7}$ Similarly, the fact that the hypothetical rule would eliminate the distinction between senior and junior debt permits the managers to finance unduly risky projects with new loans at the expense of earlier obligations,

7. See Barry E. Adler, Bankruptcy and Risk Allocation, 77 CORNELL L. REv. 439, 473-76 (1992). For a general description of debt's potential efficiency benefits, see, for example, Sanford J. Grossman \& Oliver D. Hart, Corporate Financial Structure and Managerial Incentives, in THE ECONOMICS OF INFORMATION AND UNCERTAINTY 107 (John J. McCall ed., 1982); and Stephen A. Ross, The Determination of Financial Structure: The Incentive-Signalling Approach, 8 BELL J. ECON. 23 (1977). 
which might otherwise have been protected through senior status. ${ }^{8}$ Viewed from the perspective of the time firms seek investment, all might lose from these consequences of such a rule. Thus, a regime that honors absolute priority can yield efficiencies unavailable from a regime that does not.

It is important not to misinterpret the conclusion that absolute priority matters. Generally, the priority that must be absolutely honored is a creature of contract. ${ }^{9}$ And the contracts among investors need not adhere to the typical, if implicit, assumption that holders of debt claims against or equity interests in a firm are as distinct from one another as are the claims and interests themselves. We assume, therefore, that strict adherence to absolute priority is a proper objective of bankruptcy law even though we recognize that a firm will not always find it desirable to eliminate a junior holder's interest even when seniors are not to be paid in full. For example, the generally favorable disciplinary influences of debt's priority notwithstanding, investors in a firm might wish to provide the firm's managers with a limited stake in the firm despite insolvency. Such a stake may induce the managers to be more careful with the assets of the firm after it becomes insolvent but before the bankruptcy process can intervene. ${ }^{10}$ Even after bankruptcy commences, creditors of an insolvent firm may wish to provide the debtor's maragers with a stake in the enterprise where the managers have developed firm-specific human capital essential to the

8. See Alan Schwartz, A Theory of Loan Priorities, 18 J. Legal Stud. 209 (1989). For an explanation of why early debt is not always high priority, see Barry E. Adler, An Equity-Agency Solution to the Bankruptcy-Priority Puzzle, 22 J. LEGAL STUD. 73 (1993).

9. A firm can. of course, be subject to obligations of nonconsensual creditors such as tort victims. These creditors cannot adjust their relationships with a firm to achieve optimal incentives. But the law can, in principle, award such creditors first priority and thus largely force consensual investors to internalize the costs imposed on those who cannot contract. Cf. Henry Hansmann \& Reinier Kraakman, Toward Unlimited Shareholder Liability for Corporate Torts, 100 YALE L.J. 1879 (1991) (proposing that satisfaction of tort claims extend beyond priority against a debtor's assets to the shareholders' assets). That the law does not maximize tort-claim recovery is not relevant to our discussion here. Indeed, the prospect of nonconsensual creditors altogether is inapposite to our discussion of how consensual investors may arrange their priorities. Thus, we do not again refer to nonconsensual creditors.

A reader who is interested in the relative importance of the claims filed in business bankruptcy cases should consult the Business Bankruptcy Project (principal investigators, Teresa Sullivan, Elizabeth Warren, and Jay Lawrence Westbrook), which has collected data on more than 3500 business cases from twenty-three judicial districts and has recorded detailed information on tens of thousands of the claims filed in those bankruptcies. For an overview of the research study, see Elizabeth Warren \& Jay Lawrence Westbrook, Financial Characteristics of Businesses in Bankruptcy, 73 AM. BANKR. L.J. 499 (1999). Preliminary (but yet unpublished) results from this study reveal that claims based on contract substantially outnumber claims based on tort.

10. This may justify the creation of a perverse incentive at work prior to insolvency. Adler, supra note 7, at 473-75 (describing the trade-off between pre- and post-insolvency investment incentives); see also Barry E. Adler, Finance's Theoretical Divide and the Proper Role of Insolvency Rules, 67 S. CAL. L. REV. 1107, 1111-31 (1994) (collecting references to the literature in support of such distribution); Paul Povel, Optimal "Soft" or "Tough" Bankruptcy Procedures, 15 J.L. ECON. \& ORG. 659 (1999) (describing the same tradeoff); Alan Schwartz, A Contract Theory Approach to Business Bankruptcy, 107 YALE L.J. 1807 (1998) (describing and modeling the potential desirability of a distribution to equity from the assets of an insolvent firm). 
debtor's continuation as a viable concern." But a limited stake in an insolvent firm for a firm's managers does not imply a breach in absolute priority. Instead, investors can simply grant the managers some debt, or other high-priority claim, against the firm, perhaps in addition to the managers' traditional equity interest. A bankruptcy regime that honors contracts, then, allows investors to be the masters of the applicable distribution scheme and the consequent incentives, while a regime that dishonors contractual priority necessarily interferes with such a scheme and incentives. ${ }^{12}$ Thus, at least in the common situation when investors easily can choose and adjust to the terms that suit them, ${ }^{13}$ absolute priority is at least as good as, and will frequently be better than, any imposed alternative regardless of the optimal set of distributions.

\section{B. Market vs. Nonmarket Determination}

Bankruptcy law, in the United States and elsewhere, ostensibly honors absolute priority. When classes of claims or interests are held by those who disagree over whether a reorganization plan honors such priority, the plan will be confirmed only after a judicial valuation determines that priority would be honored. A determination of absolute priority, however, does not, in fact, assure adherence to such priority. Not only do judges lack the business expertise of individual capital investors, but also a judicial valuation cannot benefit from the collective wisdom of market investors in the aggregate. As a result, even unbiased judges make mistakes that a market process would not permit. ${ }^{14}$ This observation has not been lost on either scholars or the courts. Recent years have seen a number of proposals for market-based reform of bankruptcy law..$^{15}$ And the Supreme Court

11. See Douglas G. Baird \& Robert K. Rasmussen, Priority Rights, Control Rights, and the Conceptual Foundations of Corporate Reorganizations, 87 VA. L. REV. (forthcoming 2001).

12. See Adler, supra note 10, at 1111-31 (showing that purportedly desirable distributions accomplished through deviation from absolute priority could be replicated through contracts among investors). See generally LUCIAN ARYE BEBCHUK, USING OPTIONS TO DIVIDE VALUE IN CORPORATE BANKRUPTCY 9 (Nat'l Bureau of Econ. Research, Working Paper No. 7614, 2000) (modeling an option approach to a flexible distribution scheme), available at http://papers.nber.org/papers/W7614.

13. There is a live debate about the circumstances under which investors can so choose and adjust. Compare Lucian Arye Bebchuk \& Jessie M. Fried, The Uneasy Case for the Priority of Secured Claims in Bankruptcy, 105 YaLE L.J. 857 (1996), with Barry E. Adler, Secured Credit Contracts, in The New Palgrave Dictionary of ECONOMICS AND THE LAW 405 (Peter Newman ed., 1998). We do not enter this debate here and, for simplicity, assume that all investors can do what at least many can, which is control the terms of finance.

14. Moreover, there is reason to believe that any such error, even of an unbiased judge, would not itself be unbiased. See infra note 27 and accompanying text.

15. E.g., Phillippc Aghion ct al., The Economics of Bankruptcy Reform, 8 J.L. ECON. \& ORG. 523 (1992); Baird, supra note 4; Douglas G. Baird, The Uneasy Case for Corporate Reorganizations, 15 J. LEGAL STUD. 127 (1986); Bebchuk, supra note 6; Roe, supra note 5; cf. Barry E. Adler, Financial and Political Theories of American Corporate Bankruptcy, 45 STAN. L. 
recently decided Bank of America National Trust \& Savings Ass'n v. 203 North LaSalle Street Partnership, ${ }^{16}$ in which the Court disallowed a reorganization plan because the bankruptcy judge did not put to a market test the judge's conclusion that the plan honored absolute priority. It is not yet clear whether this opinion implies that a market test is required in all contested reorganization cases, known as "cramdowns," but the case certainly represents a step in that direction. The dilution mechanism we propose here has general advantages over other market-based proposals for reform of bankruptcy law. Moreover, our mechanism alone among these proposals easily can be incorporated as a market test for absolute priority in a cramdown under current law, because absent a dispute over valuation, or until the point of such a dispute, the bankruptcy process can proceed as under current practice.

Some elaboration will clarify the roles of markets and courts in the context of the bankruptcy process. These roles, and the connection between them, are best illustrated by the LaSalle case itself. In LaSalle, the Supreme Court considered a reorganization plan that adhered to absolute priority in the view of the plan proponents but not in the view of the plan's (more senior) opponent. The proponents were an insolvent firm's pre-bankruptcy equity shareholders, who sought to contribute new capital in exchange for a continuing equity interest in the debtor. The firm's creditor would receive debt obligations against the refinanced and reorganized debtor. The opponent creditor was dissatisfied with this contribution and sought to block the plan under subsection 1129(b)(2)(B)(ii) of the Bankruptcy Code, ${ }^{17}$ which prohibits confirmation of a plan if a class below a class in dissent is to receive any property under the plan "on account of" that lower class's interest. The bankruptcy court believed that the debtor's old equity holders were to receive property on account of the new contribution, not on account of their old interest, even though old equity alone had an opportunity to propose a contribution. The bankruptcy court thought that the new contribution provided satisfactory compensation for the continuing equity interest and approved the plan over the creditor's objection. The Supreme Court held that the bankruptcy court had erred in confirming the plan notwithstanding the lower court's judgment that the proposed contribution sufficed to assure absolute priority. That is, as a matter of statutory interpretation, the Court held that the continuing interest was "on account of" the old equity interest. ${ }^{18}$

REV. 311 (1993) [hereinafter Adler, Financial and Political Theories] (exploring one such approach); Barry E. Adler, A Theory of Corporate Insolvency, 72 N.Y.U. L. REV. 343 (1997) [hereinafter Adler, Corporate Insolvency] (describing ex ante insolvency approaches that dispense with ex post valuation altogether).

16. 526 U.S. 434 (1999).

17. 11 U.S.C. $\$ 1129$ (b)(2)(B)(ii) (1994).

18. LaSalle, 526 U.S. at $442-43$. 
Doctrine aside, central to the LaSalle opinion is the Court's belief that markets are better equipped than judges to value a business. The Court focused on the fact that, as the pre-bankruptcy shareholders and managers of the debtor, the plan proponents exercised an exclusive right under the Bankruptcy Code to propose a reorganization plan through which they sought to purchase a continuing interest in the debtor:

Under a plan granting an exclusive right, making no provision for competing bids or competing plans, any determination that the price was top dollar would necessarily be made by a judge in bankruptcy court, whereas the best way to determine value is exposure to a market. This is a point of some significance, since it was, after all, one of the Code's innovations to narrow the occasions for courts to make valuation judgments, as shown by its preference for the supramajoritarian class creditor voting scheme in $\S 1126(c)$. In the interest of statutory coherence, a like disfavor for decisions untested by competitive choice ought to extend to valuations in administering subsection (b)(2)(B)(ii) when some form of market valuation may be available to test the adequacy of an old equity holder's proposed contribution. ${ }^{19}$

The reorganization plan at issue in LaSalle showed one version of a cramdown plan. In the case, the plan proponents did not contend that the creditor was to be paid in full but offered only that the creditor was to receive its due. That is, the proponents argued that the holder of a senior claim should be indifferent between receiving, on the one hand, a fractional payment from all of the debtor's assets, and on the other hand, the same fractional payment from a portion of the debtor's assets in which the remainder of the assets have been newly contributed by the holder of a junior interest. In another sort of cramdown, where the plan proponents make no new contribution, the proponents claim that they are entitled to retain an interest in the reorganized debtor, despite the dissent of a class, because in the junior proponents' estimation the senior dissenters are to be paid one hundred cents on the dollar and thus have no legitimate ground for objection. LaSalle is not clear on whether a market valuation would be required in this latter sort of cramdown as well as in the former. The doctrinal issues would differ somewhat, but the rationale of the Court's opinion applies as well to either type of cramdown plan. ${ }^{20}$ Markets evaluate

19. Id. at 457-58 (footnote and citations omitted); see also Norwest Bank Worthington v. Ahlers, 485 U.S. 197, 207 (1988) ("[T]he Code provides that it is up to the creditors-and not the courts-to accept or reject a reorganization plan which fails to provide them adequate protection or fails to honor the absolute priority rule.").

20. In LaSalle, the Court simply assumes that absolute priority is the appropriate standard because the Bankruptcy Code incorporates this standard. The Court therefore does not address the ex ante benefits of absolute priority discussed above in Section II.A. Independent of those 
assets more accurately than do judges and may do so at lower transaction costs. $^{21}$

Regardless of cramdown type, where LaSalle requires a market valuation, there remains the question of how a court is to conduct it. The Court offers no clear guidance on this subject, which is crucial to the success of any integration between current bankruptcy reorganization law and market valuation. Such integration is not, in principle, necessary. In theory, one might dispense with reorganization altogether in favor of market valuation. In the simplest version of this approach, a bankruptcy court might simply sell the debtor, either piecemeal or as a going concern for cash (by auction or market-tested negotiated agreement), and then distribute the cash in accordance with absolute priority. We discuss this and related proposals near the end of this Article.

A pure market process, however, is not generally available under current bankruptcy practice, which employs a structured negotiation among holders of claims and interests. This negotiation is backed, if necessary, by judicial determination of a result, as was the case in LaSalle. The focal point of such negotiation is the bankruptcy reorganization plan, which is typically proposed by the debtor's managers, on their own behalf or that of the debtor's junior interests. These managers or holders of junior interests are often indispensable to the debtor's productive continuation of business activity, if such continuation is to occur. Thus the bankruptcy law, in the United States and elsewhere, gives these key players a chance to propose a plan that may include themselves, regardless of whether they have the funds necessary to buy out the holders of senior claims. The law requires that the plan follow absolute priority, but if the plan proponents can make the case

benefits, given absolute priority, a market valuation is important because judicial error can otherwise lead to inefficient investment ex post. For example, a debtor's pre-bankruptcy shareholders might attempt to convince a court both that the debtor is solvent and that the debtor should continue in business even if in fact the firm is both insolvent and more valuable in piecemeal liquidation. Old equity will receive a share of the debtor's value only if the court can be so misled, as the cash prices received at a piecemeal liquidation sale will clearly reveal the debtor's true solvency state. See Barry E. Adler, The Emergence of Markets in Chapter 11: A Small Step on North LaSalle Street, 8 SUP. CT. ECON. REv. 1, 9-20 (2000).

21. Although estimates vary, it is well established that judicial valuations in cramdown, or settlements in prospect of the cramdown process, yield violations of absolute priority. The direct and indirect costs-e.g., professional fees and distraction of management-imposed by the reorganization process, moreover, can exceed the costs of an open market sale of assets similar to those being valued, as the direct costs alone of the former are comparable to the costs of the latter. For a standard analysis of both absolute priority violations and the direct costs of bankruptcy reorganization, see Lawrence A. Weiss, Bankruptcy Resolution: Direct Costs and Violation of Priority of Claims, 27 J. FIN. ECON. 285 (1990). For a caution about overstated indirect costs, however, see Gregor andRade \& STEVen N. Kaplan, How COSTly Is FinanCial (NOT ECONOMIC) DISTRESS?: EVIDENCE FROM HIGHLY LEVERAGED TRANSACTIONS THAT BECAME DISTRESSED 3-4 (Nat'l Bureau of Econ. Research, Working Paper No. 6145, 1997), available at http://www.nber.org/papers/w6145. See generally Adler, Corporate Insolvency, supra note 15 (collecting sources on the theory and empirical evidence of absolute priority violations and the costs of reorganization). 
that the plan qualifies, ${ }^{22}$ then the court will confirm rather than sell the debtor's assets out from under the proponents. A core benefit of having judges confirm these plans is to avoid putting the new owners to the burden of renegotiating the proponents' continued involvement (beyond the limited, court-supervised negotiation inherent in the confirmation process). ${ }^{23}$

Although some analysts are drawn to the simplicity of the market as a substitute for bankruptcy's structured negotiation, even at the expense of

22. To confirm a plan over dissent, the plan must satisfy a number of conditions. First, if there is an impaired class of claims under the plan, at least one impaired class of claims must accept the plan as a class. 11 U.S.C. $\$ 1129(\mathrm{a})(10)$. As a general matter, an impaired class of claims is one that the plan would not reinstate on the claims' original terms. $I d$. $\$ 1124$. Note that "impairment" is a term of art. A class of claims is impaired whether or not the plan proponents, or a bankruptcy judge for that matter. determines that the holders will be fully compensated for their claims. Class approval is also defined by the Bankruptcy Code. In general, a class of claims accepts the plan whenever the plan is accepted by creditors within the class who hold at least twothirds in amount and more than one-half in number of the claims in that class. Thus, taken together, while an individual creditor may be unable to block a reorganization plan, any creditor with more than a one-third stake in a class of claims in an impaired class can block the plan, regardless of any judicial valuation, unless another impaired class accepts the plan.

There are other hurdles, even if a plan garners the acceptance of an impaired class but not of all creditors or all classes. If a dissenter is in a class of claims or interests that as a class accepts the plan, a court must be satisfied that the dissenter will receive property under the plan worth at least as much as it would have received in a liquidation. $I d . \$ 1129(\mathrm{a})(7)(\mathrm{B})$. If a dissenter is in a class of claims or interests that as a class fails to accept the plan, a court must be satisfied that the dissenter will receive property under the plan worth an amount equal to full satisfaction of its claim or an amount equal to its by-class ratable portion of the residual interest in the value of the firm after higher priority claims or interests are satisfied in full. $l d$. $\$ 1129(\mathrm{~b})(1)$-(2). As a matter of bankruptcy parlance, this last condition alone is referred to as the absolute priority rule.

Despite these creditor protections within the Bankruptcy Code (those described here as well as others that are not relevant), often the only one that bites is the absolute priority rule. If plan proponents are creative, and they often are, a plan can be proposed that includes a friendly impaired class, one that will approve the plan despite objection from another impaired class. (To satisfy $\S 1129$ (a)(10), the friendly class need not have the same priority as the dissenter class.) Similarly, the rights of an individual dissenter within an accepting class may prove no obstacle even to an otherwise objectionable plan if the debtor's piecemeal value-the hypothetical benchmark under $\$ 1129(\mathrm{a})(7)$ - is low compared to the debtor's going-concern value. Only a class - not an individual within a class-may insist on absolute priority to the full extent of the debtor's going-concern value.

23. We assume here and hereafter that negotiation costs are positive and significant despite the theoretical prospect of a unique equilibrium bargain that would be reached instantaneously and would thus be costless. See Ariel Rubinstein, Perfect Equilibrium in a Bargaining Model, 50 ECONOMETRICA 97 (1982) (hypothesizing such a unique bargaining solution). When information is asymmetric, which may be common, the instantaneous Rubinstein solution will not obtain, even by the terms of the Rubinstein model itself. Moreover, the Rubinstein solution is controversial even where information is perfectly symmetric. See Robert Sugden, Rational Bargaining, in FOUNDATIONS OF DECISION THEORY 294, 308 (Michael Bacharach \& Susan Hurley eds., 1991) (noting that the Rubinstein analysis can "show us what the uniquely rational solution to a bargaining game would be, were such a solution to exist. But we still have no proof that a uniquely rational solution exists."); $c f$. ALAN SCHWARTZ \& JOEL WATSON, ECONOMIC AND LeGal ASPECTS OF COSTLY Recontracting (Yale Law Sch., Law \& Econ. Working Paper No. 242, 2000) (describing potential benefits to costly contracting), available at http://papers.ssm.com/paper.taf?abstract_id=224444. Theory aside, it is commonly believed that negotiation among constituents to an insolvent firm is costly. See supra note 21. 
renegotiation between purchasers and former owners, ${ }^{24}$ others are not. For example, in a critique of reform proposals, the Honorable Samuel Bufford, a bankruptcy judge, champions current bankruptcy reorganization practice, despite its imprecision and costs, ${ }^{25}$ and accuses would-be reformers of naivete. ${ }^{26}$ Judge Bufford defends the current process through which an insolvent debtor's managers or equity investors are permitted to retain control free from what he deems the destructive interference of creditors. ${ }^{27}$ The problem with creditors, according to Bufford, is that they "usually do not have the background and experience needed to run the businesses that they finance: this is not their area of expertise." ${ }^{28}$ Moreover, Judge Bufford opposes any reform that would require management or equity investors to pay creditors for the right to continue in control of, or retain the residual interest in, a financially distressed debtor. Bufford is not placated by the argument that junior interest-holders could, if they lacked funds, resort to the market for needed capital. Bufford, like the kindred spirits for whom he speaks, fundamentally doubts that capital markets are or can be sufficiently informed to serve as a general source of finance for a financially distressed firm. In Bufford's words, "[d]ebtors need an opportunity to suspend the rights of creditors because markets are so inefficient." 29 Bufford is also dubious of the market's ability to establish the necessary relationships among investors and managers. He opines that "[b]ankruptcy is overwhelmingly a result of imperfect markets and high transaction costs." 30 Bufford seems untroubled by the observation that the bankruptcy process he supports interferes with the contractual priority that investors had established at the time of investment. According to Bufford, "[b]ankruptcy law has always been conceived as an involuntary impairment of contract rights." ${ }^{31}$

Yet, as we have discussed, there are important efficiency consequences to contractual priority, a fact the Supreme Court implicitly recognized in

24. See infra Part VI (discussing the alternatives to bankruptcy reorganization).

25. See supra note 21 . Note, moreover, that juniors' option to propose a reorganization plan, an option codified in 11 U.S.C. $\$ 1121$, can allow juniors to benefit systematically even from unbiased but variable judicial valuations. See Barry E. Adler, A Simple Game-Theoretic Solution to the Tension Between Cramdown and Holdup in Corporate Reorganization (Feb. 9, 2000) (unpublished manuscript, on file with author). On the other hand, some analysts, particularly practitioners, believe that senior creditors, specifically secured creditors, take advantage of the reorganization process at the expense of juniors. See Samuel L. Bufford, What Is Right About Bankruptcy Law and Wrong About lts Critics, 72 WASH. U. L.Q. 829, 842 (1994). Suffice it to say here that there is reason to believe that the distribution of potential outcomes in each case is something other than unbiased results with absolute priority at its mean.

26. Bufford, supra note 25 , at $841-42$.

27. Id. at $836-38$.

28. Id. at 843 .

29. Id. at 846 .

30. $I d$.

31. Id. at 842 . 
LaSalle. Consequently, an important objective of this Article is to explain how our dilution mechanism uniquely addresses both the market imperfections that trouble Judge Bufford and the perceived need for market discipline on the reorganization process. The advantages of the dilution mechanism fit into two broad categories: the potential for negotiation-free retention of equity by essential illiquid holders of junior interests and the potential for such holders of junior interests to receive value that approaches their due share despite both their own illiquidity and the absence of a robust outside market.

\section{THE SIMPLE ECONOMICS OF DILUTION}

This Part will present a more formal analysis of the senior dilution mechanism and its effectiveness as a valuation tool to implement absolute priority. But before proceeding to this analysis in Sections III.B and III.C, it is useful to relate this mechanism to the "passivity pill" mechanism first proposed by Robert Daines and Jon Hanson in the corporate law context. ${ }^{32}$

\section{A. Dilution and "Topping-Off" Methods of Valuation}

Our dilution mechanisms are directly inspired (albeit in a convoluted way to be explained herein) by the Daines and Hanson analysis. Daines and Hanson suggested that target managers should be allowed to resist tender offers only if they were willing to post a "resistance bond" - a promise to compensate their shareholders for any shortfall in stock value (at some certain future date) relative to the tender offer price. The authors understood that it was not appropriate to measure the amount that the managers might have to pay as simply the difference between the tender offer price and the future stock price: "[T]he problem with tying the bonder's obligation to market price is that stock market prices will, once there has been resistance bonding, reflect more than just shareholders' estimates of the firm's value...." 33

Even if the target corporation were mismanaged, the stock price might not fall to its true fundamental value, because shareholders would capitalize the expected manager payment as well as the traditional expected free cash flow from the ordinary course of business. ${ }^{34}$ In essence, such a market price

32. Robert M. Daines \& Jon D. Hanson, The Corporate Law Paradox: The Case for Restructuring Corporate Law, 102 YALE L.J. 577, 622-24 (1992) (reviewing FRANK H. EASTERBRoOK \& Daniel R. Fischel, THE ECONOMIC STRUCTURE OF CORPORATE LAW (1991)).

33. Id. at 622 .

34. For a discussion of what equilibrium damages would be under a naive topping-off mechanism, see infra note 36 and accompanying text. 
approach for measuring managerial damages would suffer from a kind of circularity: The court would be looking to the market price to calculate damages, but the market price would be trying to capitalize, among other things, the expected court damages. ${ }^{35}$

Daines and Hanson's important innovation was to avoid this circularity problem. They proposed what we call a "topping-off" mechanism for determining how much the managers owed the target at the future date. If the target management had (as a precondition to fending off a hostile tender offer) promised that the target stock would be worth at least $\$ 100$ two years in the future, and if at the end of this time the stock price was less than or equal to $\$ 100$, then the management would have a duty to make gradual payments to the firm until the stock price rose to $\$ 100.01$.

While this topping-off mechanism was first proposed in the takeover context, it might have applications in several other settings. For example, imagine that Bill Gates tortiously injures a rival corporation. Trying to measure the size of the injury by the change in stock price would again give rise to a kind of circularity, because the rival's stock price after the tort, but before the award, would tend to capitalize the expected payment (which itself would be a function of the stock price change) ${ }^{36}$ Instead of setting

35. Cf. Janet Cooper Alexander, The Value of Bad News in Securities Class Actions, 41 UCLA L. REv. 1421, 1435 (1994) (discussing a similar circularity problem with regard to inferring damage from the price movement at the time of a corporate fraud).

36. The term "circularity" might suggest to readers that there would not be an equilibrium level of damages. But Rob Gertner suggested to us that there may be simple models for which a fixed-point equilibrium exists. Imagine that the actual injury is $I_{\mathrm{A}}$ but that the judicially determined injury $l_{j}$ is simply equal to the difference between the pre-tort stock price $\left(P_{0}\right)$ and the post-tort stock price $\left(P_{i}\right)$ :

$$
I_{J}=P_{o}-P_{1}
$$

If the stock market capitalizes both the effect of the tort and the expected court award, then the post-tort stock price should equal:

$$
P_{1}=P_{0}-I_{A}+I_{F}
$$

Substituting the damage equation into the stock price equation, we find:

$$
\begin{aligned}
& P_{1}=P_{O}-I_{A}+P_{O}-P_{1} \\
& 2 P_{I}=2 P_{o}-I_{A} \\
& P_{I}=P_{O}-\left(I_{A} / 2\right) .
\end{aligned}
$$

This suggests that the stock price may only fall half as much as actual damages, so that the judicially determined award would only compensate the plaintiff corporation for half of its injury:

$$
I_{s}=I_{A} / 2
$$

In this equilibrium, the stock price would not move when Gates paid the damage amount because the market would have already capitalized both the award and the actual injury.

It may be interesting to note that compensation for more than half of the plaintiff's injury could be accomplished by setting the plaintiff's recovery as a multiple of the difference between the pre-tort stock price and the post-tort stock price. For example, if that multiple were two, the 
damages equal to the simple stock price change, a topping-off approach would have Gates pay money to the rival corporation until its stock price slightly exceeded its pre-tort level. ${ }^{37}$

Although this mechanism is elegant, it might not work precisely as designed. In particular, we worry about fluctuation in the underlying value of the target corporation during the topping-off period, which could bias the outcome of the process. ${ }^{38} \mathrm{We}$ believe that fixed-price auctions are likely to provide a more resilient method of solving the circularity problem. ${ }^{39}$ Fixed-

judicially determined award would compensate the plaintiff corporation for two-thirds of its injury after a fall in the stock price that was equal to one-third of that injury. Indeed, as the multiplier increased, the undercompensation would approach zero. However, as the multiplier increases, the predicted drop in stock price also decreases, and the mechanism could become intolerably noisysubject to market fluctuations unrelated to the tort injury-well before undercompensation became trivial.

37. It probably would be useful to use a beta-adjusted stock price. If the general stock market had gone up $10 \%$ since the tort and if the rival's stock had a beta of 1.2, then (ignoring dividends for the moment) Gates should be required to pay in money until the rival's stock price exceeds $112 \%$ of its price just before the tort was inflicted. See Daines \& Hanson, supra note 32, at 624 n.219.

38. Imagine, for example, that Gates tortiously destroys $10 \%$ of his rival's business worth $\$ 1,000,000$ prior to the injury and that the proposed remedy is for Gates to pour money into the rival firm until the rival's shares reach a trading price above $\$ 100$ per share. Now assume that shortly after the remedy is announced, the value of the rival's assets unaffected by the tort decline in value by $\$ 200,000$. If no other changes take place, and the shareholders do not withhold their shares strategically, Gates will pay a total of $\$ 300,000$ in damages before the share price exceeds $\$ 100$ even though he caused only $\$ 100,000$ of injury. Conversely, if the rival's unaffected assets appreciated, rather than depreciated, by $\$ 200,000$, Gates might then pay no damages before the share price exceeds $\$ 100$, but if each event is equally likely his expected liability would be excessive as $(0.5)(\$ 300,000)+(0.5)(\$ 0)=\$ 150,000$, an amount greater than the $\$ 100,000$ injury.

39. Carving out separately traded rights represents another way of solving the circularity problem. Under a "carve-out" solution, shareholders of the target corporation, or shareholders of the rival corporation in the Microsoft example, would be given separately tradeable rights that would receive the proceeds of any litigation payment. Carving out separately tradeable rights destroys the circularity problem because the price of the stock itself would no longer reflect the expected value of litigation. As a result, to continue with the Microsoft illustration, the share price of the Gates rival would immediately fall to $\$ 90$. This fall of $\$ 10$ would at once establish the value of the tradeable compensation rights at that amount.

Carve-out rights are increasingly being seen in real-world transactions. For examplc, in the 1994 battle for Paramount, Viacom gained its ultimate advantage over rival bidder QVC by including in its bid a so-called contingent value right. Stephen Fraidin \& Jon D. Hanson, Toward Unlocking Lockups, 103 YALE L.J. 1739, 1833 n.372 (1994). For a description of the device employed by Viacom, and how it came to be, see John Cassidy, Paramount Victory Leaves Viacom Exposed. TIMEs (London), Feb. 20, 1994, § 3, at 5; and John Greenwald, The Deal That Forced Diller To Fold, TIME, Feb. 28, 1994, at 50. As with the passivity pill, a would-be management team promised to compensate shareholders if the future share price was less than a certain amount. But instead of being structured so that payments would be made to the corporation until the stock price exceeded a particular amount, the contingent value rights were carved out and obligated the payor to pay the simple shortfall between the stock price and the guaranteed amount (within certain limits). Litigation carve-outs are also being traded with regard to some claims by savings and loan institutions (S\&Ls) regarding the federal government's potential liability under United States v. Winstar Corp., 518 U.S. 839 (1996). In Winstar, the United States Supreme Court found that the federal government, by enacting the Financial Institutions Reform, Recovery, and Enforcement Act of 1989 (FIRREA), Pub. L. No. 101-73, 103 Stat. 183 (codified in scattered sections of 42 U.S.C.), had breached certain contracts with S\&Ls that had agreed to take over failing $S \& L$ counterparts and remanded the case for a consideration 
price auctions still represent a kind of topping-off, as the proper distribution of value is determined through incremental increases in transferred property. But this implementation requires market participants to submit firm, nonrescindable offers concerning their willingness to buy or sell shares at the same topping-off price conditional on different size payments. As applied to resistance bonding, this would mean that the court would aggregate the demand and supply for the target company's stock conditional on different damage payments and set damages equal to the amount at which supply equaled demand. For example, if the target management had promised that the target corporation's stock would be worth at least $\$ 100$ at time $T$, a court (or an investment banker working pursuant to the resistance bond contract) would solicit and aggregate nonrescindable offers to buy and sell the target company stock for various potential damage payment levels that might be made to the target corporation. If demand to buy shares was always greater than the offers to sell shares (even at a damage payment of $\$ 0$ ), then the court would order a zero-damage payment. If at low damage-payment amounts, however, the offers to sell at $\$ 100$ were greater than the offers to buy, then the court would increase the damage payment amount up to the level at which net demand for shares at $\$ 100$ per share was zero.

We see our senior dilution mechanism as a kind of inverted topping-off mechanism. Instead of forcing a third party to pour money into a corporation until its shareholders are made whole, we force the senior parties to dilute down (or siphon off) ${ }^{40}$ the value of their stock until its value equals no more than the amount that they are owed. In what follows, we focus on the fixed-price auction version of our dilution mechanism, primarily because such an implementation fits more easily into current bankruptcy law. ${ }^{41}$ We turn now to a more complete discussion of the dilution mechanism itself. ${ }^{42}$

of damages. Winstar, 518 U.S. at 910 . There are now over 100 Winstar-related cases. In the first case calculating damages for a single bank, the court awarded damages of more than $\$ 900$ million. Glendale Fed. Bank, FSB v. United States, 43 Fed. Cl. 390, 410 (1999). The substantial size of potential damages has led some plaintiffs to spin off their claims against the government as separate assets. See Leonard Bierman et al., On the Wealth Effects of the Supervisory Goodwill Controversy, 22 J. FIN. RES. 69, 71 (1999).

40. We note that the Article is awash with liquid metaphors. Cf. Samuel Issacharoff \& Pamela S. Karlan, The Hydraulics of Campaign Finance Reform, 77 TEX. L. REV. 1705, 1705 (1999).

41. But it would also be at least theoretically possible to use a carve-out mechanism for valuing firms in bankruptcy. Imagine again that senior claimants represent that the reorganized firm is worth less than their outstanding debt, while juniors claim the firm is worth more than the outstanding senior debt. Under a carve-out mechanism, senior creditors would be given $100 \%$ of the new stock in the reorganized firm. More generally, senior claimants would be given the initial choice of how to divide the stock in the reorganized firm. For example, if senior creditors (who were owed $\$ 100$ ) represented that the reorganized firm would be worth $\$ 120$, they would be given five-sixths of the new stock and junior claimants would be given the remaining one-sixth. Senior claimants would then have a separately tradeable duty to pay junior claimants for any amount by 


\section{B. A Numerical Example}

We begin here by working through a numerical example. Imagine a firm with two priority classes of unsecured claimants-senior and junior. At the time of bankruptcy, each is nominally owed $\$ 100$. The parties agree that the capital structure of the reorganized firm will be all stock, but disagree about how this stock should be divided between the two classes, because the parties disagree about the firm's value. ${ }^{43}$ The senior claimants argue that the reorganized firm is only worth $\$ 90$, so that they should have

which the total value of their stock exceeded $\$ 100$ when the stock was initially traded. That is, senior claimants would receive an independent obligation (a potential liability, not an asset) to pay junior claimants any amount by which the total reorganized stock value exceeded $\$ 100$ as soon as the reorganized stock initially traded. Given the high volatility that sometimes accompanies the initial trading of a new security, see Royce de R. Barondes, Adequacy of Disclosure of Restrictions on Flipping IPO Securities, 74 TUL. L. REV. 883, 884 (2000), it might be prudent to have the carve-out liability amount turn on the stock price that prevails after a few days of trading.

As in the Microsoft illustration above, one might worry about market manipulation. Imagine, for example, that even though the reorganized firm is worth $\$ 150$, the senior claimants have chosen to take all of the stock in the reorganized firm and the independent compensation liability. Senior claimants would have an incentive to depress the price of the reorganized firm's stock when it goes public so as to limit the amount of compensation they have to pay junior claimants. But to lower the stock price, they will have to stand ready to sell stock to all comers who demand stock at an artificially depressed price. Junior claimants can protect themselves from such shenanigans by making firm offers to buy at depressed prices. Conversely, senior claimants can protect themselves from junior claimants' strategic incentive to inflate the initial stock price artificially by simply offering to sell all of their shares at the inflated price. As in the Microsoft illustration, manipulation would be more difficult the more homogeneous (and the more vigilant) the investors. The risk of manipulation aside, the initial stock price should be the amount at which supply equals demand-and so the carve-out method (like the fixed-priced auction method) gauges the price that fully compensates junior claimants. While bankruptcy carve-outs are of theoretical interest, we focus on the dilution implementation, because it does not suffer from risk of manipulation, presents fewer difficultics than carve-outs in assuring that individual liability obligations of senior claimants would in fact be paid, and does not require an overhaul of current bankruptcy law. The mechanism could require that senior claimants post a bond in the amount of the liability before they could trade the associated shares. But such a mechanism could prove cumbersome and, in essence, a tax on liquidity. For a general discussion of the difficulty of implementing a regime of personal liability associated with publicly traded shares, see Janet Cooper Alexander, Unlimited Shareholder Liability Through a Procedural Lens, 106 HARV. L. REV. 387 (1992).

42. As noted in the Introduction, the process that can best accomplish an integration with current bankruptcy law is a "junior dilution" mechanism, through which junior claims are diluted until absolute priority is achieved. Rather than describe junior dilution now, however, we take a slightly simpler course and first describe the essentially identical, but inverted, "senior dilution" mechanism, through which senior claims are diluted until absolute priority is achieved. (The relative simplicity of senior dilution stems from the ease with which the process terminates when the junior claims are entitled to nothing. Senior dilution, moreover, is easier to compare with other market-based proposals discussed later in this Article.) A full explanation of junior dilution follows in Part V

43. The assumption that the capital structure of the reorganized firm will be all stock is merely for the ease of illustration. In practice, the new capital structure could have any combination of debt or equity as would be efficient. Shares of the company to be divided among the holders of pre-bankruptcy claims or interests would simply be vertical-priority shares of the new capital structure. So, for example, in a firm that emerged from bankruptcy with $\$ 100$ in debt and 100 equity shares, a pre-bankruptcy creditor entitled to $10 \%$ of the debtor would receive $\$ 10$ in debt and 10 equity shares. See infra note 51. 
$100 \%$ of the stock in the reorganized firm. The junior claimants argue that the reorganized firm is worth $\$ 150$, so that they should be given one-third of the stock in the reorganized firm. This is the classic valuation conflict in bankruptcy.

Under our proposed mechanism, the court would issue 100 shares in the reorganized firm to the senior claimants and would then solicit schedules of firm offers to buy or sell at a fixed price of $\$ 1$ per share conditioned upon a particular number of additional shares being issued to the junior claimants. ${ }^{44}$ Under this mechanism of senior dilution, the court would (1) issue shares to the junior claimants up until the demand (offers to buy shares at this fixed price of $\$ 1$ per share) was less than or equal to the supply (offers to sell at $\$ 1$ per share) and (2) execute sales from senior to junior claimants equal to the number of shares that junior claimants offered to buy. In our more detailed proposal, we allow third parties to offer to buy and sell shares at this fixed price (conditioning their offers once again on varying amounts of dilution), but for now we assume that only junior and senior claimants are willing and able to participate in this fixed-price auction.

To be specific, senior claimants, for example, would be asked:

(1) How many of their shares they would want to sell (at $\$ 1$ per share) if zero shares were issued free of charge to junior claimants;

(2) How many of their shares they would want to sell (at $\$ 1$ per share) if one share was issued free of charge to junior claimants;

(3) How many of their shares they would want to sell (at $\$ 1$ per share) if two shares were issued free of charge to junior claimants; and so on.

Their answers to these questions constitute what we call the "supply schedule." As the amount of potential dilution increases (i.e., the number of shares issued free of charge to junior claimants increases), the willingness of senior creditors in the aggregate to sell their shares for a fixed price of $\$ 1$ per share would increase, because selling one's shares for $\$ 1$ would look like an increasingly good deal as the number of outstanding shares ballooned. Even assuming that every individual senior claimant would offer to sell all shares or no shares depending on whether that individual believed the shares were worth less or more than $\$ 1$, supply would increase in the aggregate given the heterogeneity of valuation. For sufficiently large

44. Bidding schedules are also submitted as part of share auctions. See Robert Wilson, Auctions of Shares, 93 Q.J. ECON. 675, 680 (1979). 
amounts of dilution, all senior claimants would be willing to sell all of their shares.

Junior claimants would conversely be asked how many of the senior claimants' shares they would be willing to buy conditional on receiving free of charge a certain number of court-issued shares. For example, they would be asked:

(1) How many additional shares they would want to buy (at $\$ 1$ per share) if zero shares were issued to them free of charge;

(2) How many additional shares they would want to buy (at $\$ 1$ per share) if one share was issued to them free of charge;

(3) How many additional shares they would want to buy (at $\$ 1$ per share) if two shares were issued to them free of charge; and so on.

Their answers to these questions constitute what we call the "demand schedule." As the amount of potential dilution increases, the willingness of junior claimants in the aggregate to buy shares at a fixed price of $\$ 1$ per share would decrease, because buying at $\$ 1$ per share would look like an increasingly bad deal as the number of outstanding shares ballooned. Even assuming that every individual junior claimant would offer to buy all shares or no shares depending on whether that individual believed the shares were worth more or less than $\$ 1$, demand would decrease in the aggregate given the heterogeneity of valuation. ${ }^{45}$ For sufficient amounts of dilution, no junior claimant would be willing to buy any shares at $\$ 1$ per share.

The court would then compare the aggregate supply and demand schedules of the senior and junior claimants (and in future examples, those of any third parties willing to make firm offers to buy or sell) ${ }^{46}$ and would issue additional shares to the junior claimants free of charge until the supply of shares offered for sale was greater than or equal to the demand for shares offered for purchase at the fixed price of $\$ 1$ per share. Because the number of shares that senior claimants offered for sale would monotonically increase with the amount of dilution, and the number of shares in the aggregate offered for purchase by the junior claimants would monotonically decrease with the amount of dilution, the mechanism is assured of producing a discrete amount of dilution (that is, some noninfinite number possibly equal to zero). As shown in Figure 1, if the supply and demand curves are smoothly increasing and decreasing, respectively, then the

45. When junior claimants are illiquid, however, we show that they may offer to buy more shares as the amount of dilution increases, because pledging prospective dilution shares may relax the liquidity constraint. See infra Section IV.C.

46. We later discuss the possibility of third parties offering to "sell short" shares in the reorganized firm. See infra Subsection IV.A.3. 
monotonicity of supply and demand guarantees either zero dilution as depicted in Panel (a), or some finite positive amount of dilution as depicted in Panel (b). At the equilibrium level of dilution, the court would also execute those binding offers to buy and sell that were made conditional on this many shares being issued. ${ }^{47}$

\section{Figure 1. TWo EXAMPLES OF EQUILIBRIUM DILUTION}

(a) Zero Equilibrium Dilution

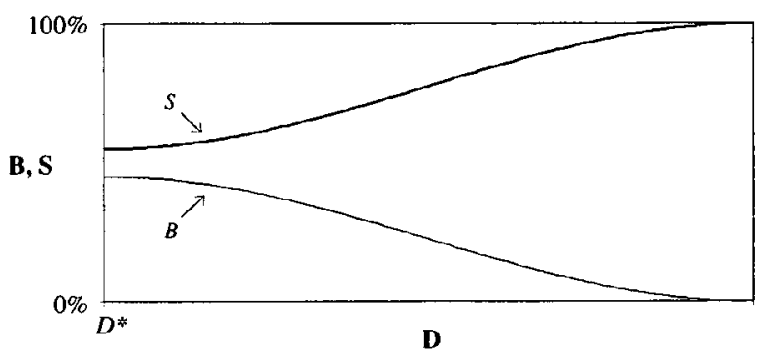

(b) Positive Equilibriun Dilution

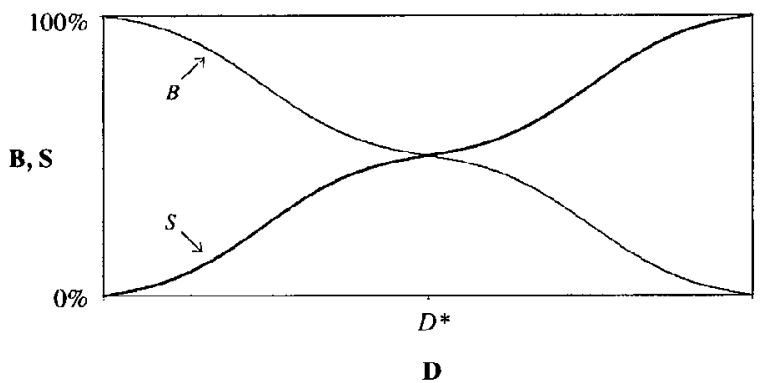

We call this a "senior dilution" mechanism because the court dilutes the value of the senior claims by potentially giving additional stock to junior claimants. But the mechanism might also be characterized as a fixedprice auction. The price is fixed (in our example, at $\$ 1$ per share) so that senior creditors will be fully compensated in the event that any dilution stock is issued to juniors. Senior claimants will be fully compensated either by actually selling some part of their stock at this fully compensating par value, or by voluntarily retaining stock in the reorganized firm when they could have sold it at par. The dilution proceeds until the net demand at the fixed price is less than or equal to zero.

47. If supply is greater than demand at the equilibrium level of dilution, a proportionate amount of all offers to sell would be executed. Details of the market clearing arc discussed below in Section III.C. 
Let us imagine how junior and senior claimants would react to such a mechanism. First, assume that, notwithstanding junior claimants' representations to the court, both junior and senior claimants believe that the reorganized firm is worth only $\$ 90$. In that case, the senior claimants are likely to offer all 100 of their shares for sale at $\$ 1$ per share regardless of the number of dilution shares issued to the junior claimants free of charge. Even with no dilution, the 100 shares of the senior claimants are worth only $\$ 0.90$ per share-hence, senior claimants have a strong incentive to offer all of their shares for sale at $\$ 1$ per share.

The willingness of senior claimants to sell all of their shares at par (even at zero dilution) would, by itself, be outcome-determinative. Dilution occurs only up to the point at which the supply equals or exceeds the demand. Because the mechanism allows junior claimants to buy no more than $100 \%$ of the senior claimants' shares, junior demand cannot exceed the senior supply. ${ }^{48}$ Moreover, it would not be an equilibrium strategy for juniors to offer to pay $\$ 1$ per share to buy a share worth only $\$ 0.90$. As shown more formally below, when all of the claimants know that the firm's value is less than the senior claimants' debt, the mechanism is likely to produce an equilibrium in which there is no dilution, and senior claimants receive all of the stock in the reorganized firm.

Now imagine instead that the firm is worth more than the amount currently owed to the senior claimants. In particular, imagine that junior claimants' representations to the court have been correct (and that senior claimants have intentionally under-represented the value of the firm), so that the firm's true value is equal to $\$ 150$. Under this scenario, junior claimants, when submitting their bids, would have a strong incentive to offer to buy all of the senior claimants' 100 shares if they were to receive no dilution shares. ${ }^{49}$ With zero dilution, there would only be a total of 100 shares outstanding so that the marginal share would be worth $\$ 1.50-\mathrm{a}$ bargain at a fixed price of $\$ 1$. Indeed, junior claimants should have a strong incentive when submitting their bidding schedules to continue to offer to buy $100 \%$ of the senior claimants' stock (100 shares at $\$ 1$ per share) as long as the number of dilution shares being issued to juniors is less than fifty. When there are fewer than fifty dilution shares, the individual share value

48. Even if the juniors submitted a bidding schedule with the maximum offer to buy ( 100 shares) when dilution was nil, the court would find that supply was equal to or less than demand without dilution and, hence, under the mechanism would issue zero shares free of charge to the junior claimants and would execute the 100 shares initially issued to the seniors to the juniors at $\$ 1$ per share.

49. Of course, junior claimants will be able to buy only if they have sufficient liquidity. When junior claimants are liquidity-constrained, dilution mechanisms may produce equilibria that do not comport with absolute priority. We show, however, that there are several factors that work to ameliorate the problem of junior illiquidity. See infra Section IV.C. 
(equaling the firm value of $\$ 150$ divided by the total number of outstanding shares) is greater than $\$ 1$.

Conversely, senior claimants will have a strong incentive when submitting their bidding schedules to offer to sell $100 \%$ of their shares if more than fifty dilution shares were issued free of charge to the junior claimants. If dilution exceeded fifty shares, the per-share value of the firm would fall below $\$ 1$ so that senior claimants would have an incentive to sell.

Junior claimants' willingness to buy all shares for dilution amounts less than fifty and senior claimants' willingness to sell all of their shares for dilution amounts greater than fifty will have the predictable effect of driving the equilibrium to the issuance of fifty dilution shares. To be sure, senior claimants will have a strategic incentive to inflate their offers to sell in hopes of reducing the equilibrium amount of dilution, and junior claimants will have a strategic incentive to inflate their offers to buy in hopes of increasing the equilibrium amount of dilution. But the next Section will show that the nonstrategic incentives of the junior claimants to buy when dilution is low and of the senior claimants to sell when dilution is high suffice to drive the equilibrium toward the amount of dilution that implements the absolute priority rule.

This simple example serves to show many of the basic attributes of the mechanism. Most important, notice that in this example the mechanism succeeds in implementing absolute priority. In the first scenario, when the firm value was less than the amount owed to senior claimants, and no trades were consummated because supply exceeded demand at all levels of dilution, the mechanism produced no dilution so that $100 \%$ of the equity in the reorganized firm was issued to the senior claimants. In the second scenario, when the firm value was greater than the amount owed to the senior claimants, the mechanism gave equity or cash to the senior claimants commensurate to the value of their claim and gave the excess value to junior claimants.

The mechanism harnesses the private information of the parties. ${ }^{50}$ Even when the court cannot observe the true value of the firm, the mechanism gives self-interested junior and senior claimants an incentive to reveal-via their bidding schedules - how much they think the firm is really worth.

As we will demonstrate, dilution mechanisms are not constrained to the assumptions of this simple example. The mechanism works at least as well

50. In this respect, the mechanism also resembles devices used by shareholders in small businesses who need to resolve deadlocked situations. For example, a shareholder agreement could allow one shareholder to pick a price and the other to buy or sell at that price. For a more general account of information-forcing valuation mechanisms, see Saul Levmore, Self-Assessed Valuation Systems for Tort and Other Law, 68 VA. L. REV. 771 (1982) (describing self-enforcing valuation schemes in other contexts). 
as any alternative valuation mechanism, even when information is incomplete, when junior claimants lack liquidity, or when multiple parties, including third parties, participate in the process. Significantly, a "junior dilution" variant of the foregoing example can be adapted to function as part of current American bankruptcy law as a response to the Court's directive in LaSalle. In this respect, our approach trumps the alternatives.

\section{A Formal Two-Player Model}

Above, we discussed a simple numeric example of how our senior dilution mechanism would operate. In this Section, we present a more formal model of the mechanism and how players would react to the mechanism in equilibrium. To begin, imagine there are two players: Senior and Junior, who are the only claimants on the assets of an insolvent corporation. For simplicity, we will assume that the capital structure of the reorganized firm will be all equity ${ }^{51}$ A court initially determines that Senior is currently owed $D e b t_{s}$ and that Junior is currently owed $D e b t_{.}{ }^{52}$ The true

51. Without loss of generality, one might alternatively assume any mixture of debt and equity instruments. In that case, instead of distributing common stock in the reorganized firm, the court would distribute pro-rata combinations of separately tradeable securities. For example, if it were determined that the firm would be more valuable with $50 \%$ common stock, $30 \%$ preferred stock, and $20 \%$ bonds, then instead of issuing, for example, $10 \%$ of the equity to Junior, the court would issue to Junior $10 \%$ of each type of security (10\% of the stock, $10 \%$ of the preferred shares, and $10 \%$ of the bonds). See supra note 43; see also Bebchuk, supra note 6, at 781-82 (discussing a similar example).

It is possible that the value of the firm will turn not only on the mixture of security types that are issued but also on the identities of owners of particular security types. HENRY HANSMANN, THE OWNERSHIP OF ENTERPRISE 68 (1996). We will return to this issue in Part VI as we discuss the relative advantages and disadvantages of different market-hamessing devices.

52. We do not describe here how a court would determine $D e b t_{s}$ or Debt. Were the firm's debt divided into plenary priority classes, this determination would be trivial, of course. In fact, however, the seniority of debt in the United States and elsewhere frequently is asset-based. That is, seniority is often limited to the value of collateral that supports a loan, with any deficiency (that is, any shortfall between the collateral value and the amount owed) being treated as a general, unsecured obligation. 11 U.S.C. $\$ 506$ (a) (1994). Thus, in practice, even if a court were to implement our dilution mechanism for the valuation of a debtor as a going concern, a judicial valuation of the collateralizing assets would be required to determine $D e b t_{s}$ and $D e b t_{j}$. This does not represent a significant shortcoming for our mechanism, however, as it is often relatively simple to value assets in isolation, while it is difficult to value assets grouped as part of a going concern. See Adler, supra note 7, at 446-47; see also Bebchuk, supra note 6 (proposing the use of options to value corporations in bankruptcy). While our mechanism offers no mitigation of a small problem (collateral valuation), it does contribute substantially to the solution of a larger one (firm valuation).

Moreover, our mechanism could be modified, or, more accurately, appended to alternative means of determining the value of collateral. For example, Adler proposes that a debtor undergoing reorganization might be empowered to make a take-it-or-leave-it offer for collateral that the debtor hoped to obtain. Adler, supra note 25. If that offer were accepted, the debtor's promise to pay the purchase price could become a priority obligation of the reorganized debtor. The dilution mechanism could then be applied between the equity class and the junior claims class or between junior and senior claims classes if different plenary priorities of claims remained after disposition of the collateral. Similarly, Bebchuk and Fried propose that a debtor undergoing 
value of the reorganized firm is $V$, which for now we assume is common knowledge between Junior and Senior, but a court can only verify that the firm is insolvent: ${ }^{53}$

$$
V<D e b t_{s}+D e b t_{j}
$$

Under a senior dilution mechanism, the court announces that it will distribute a number of shares $N_{s}$ to Senior, with $N_{s}$ set equal to $D e b t_{s}$ $\left(N_{s} \times \$ 1=D e b t_{s}\right)$. Granting Senior this many shares means that if the shares are ultimately worth $\$ 1$ per share, then Senior will be fully compensated for the debt it is owed.

The court announces that it will distribute $D^{*}$ (so-called dilution) shares to Junior, with $D^{*}$ a function of the players' bidding schedules. The court asks Senior to submit a bidding schedule indicating how many of its $N_{s}$ shares it is willing to sell at a fixed price of $\$ 1$ per share conditional on different potential amounts of dilution. We denote Senior's bidding schedule of nonrescindable sell offers as $S(D)$. Conversely, Junior is asked to submit a bidding schedule indicating how many of Senior's $N_{s}$ shares it is willing to buy at a fixed price of $\$ 1$ per share conditional on different potential amounts of dilution. We refer to Junior's bidding schedule of nonrescindable buy offers as $B(D)$.

The court requires that the bidding schedules be submitted simultaneously and tells the players that the dilution amount will be determined as the smallest dilution quantity for which Senior's offer to sell is greater than or equal to Junior's offer to buy. Or, in algebraic terms:

$$
D^{*}=\underset{D}{\arg \min } S(D) \geq B(D) .
$$

The court also informs the players that the seller will have to sell and the buyer will have to buy $B\left(D^{*}\right)$ shares at a price of $\$ 1$ per share.

Hence, there are two stages of play. In the first, the players simultaneously submit bidding schedules. In the second, the court, after

rcorganization issue nonrecourse notes against the debtor's collateral, with the proceeds to the secured creditors, and with the debtor to redeem the notes in cxchange for the collateral. Lucian Arye Bebchuk \& Jesse M. Fried, A New Approach to Valuing Secured Claims in Bankruptcy, 114 HARV. L. REV. 2386 (2001). The dilution mechanism could proceed from that point in the same manner as it would after the collateral valuation process that Adier proposes. In either case, the new obligations owed to the holders of secured claims would take their own priority class, above all unsecured obligations. As described in Subsection IV.A.2, the dilution mechanism can function with any number of priority classes.

53. This two-player model would not change if there were only one class of debt and the court could not verify that the firm was insolvent. In that case, the mechanism modeled would divide value between a creditor and an equity shareholder. We chose to describe the debtor as demonstrably insolvent merely because it may be convenient for some to think of a debtor in bankruptcy as insolvent. When we expand the model in Subsection IV.A.2 to cover multiple priority classes, it should become apparent that nothing turns on this assumption. 
aggregating the bidding schedules, simultaneously (1) issues $N_{s}-B\left(D^{*}\right)$ shares to Senior, (2) issues $D^{*}+B\left(D^{*}\right)$ shares to Junior, and (3) transfers $B\left(D^{*}\right)$ dollars from Junior to Senior. ${ }^{34}$

To determine how the players are likely to react to the mechanism, it is useful to specify the players' payoffs as functions of their underlying strategies. Junior's payoff $\left(\pi_{J}\right)$ will be:

$$
\pi_{J}=\left(\frac{D^{*}+B\left(D^{*}\right)}{N_{S}+D^{*}}\right) V-B\left(D^{*}\right)
$$

and Senior's payoff $\left(\pi_{s}\right)$ will be:

$$
\pi_{s}=\left(\frac{N_{s}-B\left(D^{*}\right)}{N_{S}+D^{*}}\right) V+B\left(D^{*}\right) .
$$

In each case, the player's payoff consists of the value of its share of the outstanding stock (the first term) plus or minus the revenue from buying or selling shares at $\$ 1$ per share (the second term).

It is straightforward to calculate how players would bid if they ignored how their bidding might affect the equilibrium amount of dilution itself $\left(D^{*}\right)$. What we call "nonstrategic" bidding schedules simply report how much the players would want to buy or sell for given (fixed) amounts of dilution. For example, examining Junior's payoff, we see that the derivative of the payoff with respect to $B$ (holding $D^{*}$ constant) is:

$$
\frac{\partial \pi_{J}}{\partial B}=\frac{V}{N_{S}+D^{*}}-1
$$

It is straightforward to see that Junior's profits increase with its offers to buy when $D^{*}<V-N_{s}$, but Junior's profits decrease with its offers to buy when $D^{*}>V-N_{s}$.

Intuitively, when the dilution amount is relatively low, it is profitable for Junior to buy Senior's shares at $\$ 1$ per share. But when dilution is relatively high, it is unprofitable to buy shares at $\$ 1$ per share. We will refer to this critical threshold $\left(V-N_{S}\right)$ as $D_{A P}$ because when dilution is required, $D_{A P}$ is the exact amount of dilution that implements the absolute priority rule regardless of how many shares are bought and sold in the ancillary

54. For now, we assume that Junior has sufficient dollars to place in escrow when submitting its bidding schedule to ensure that the court can automatically execute its conditional offers. $C f$. Robert H. Gertner \& Geoffrey P. Miller, Settlement Escrows, 24 J. LEGAL STUD. 87, 91 (1995) (discussing an analogous mechanism of self-executing offers). Below we discuss the important issue of whether Junior has sufficient liquidity to buy. See infra Section IV.C. 
executions. ${ }^{55}$ Remember that $N_{s}$ was set to equal $D e b t_{s}$, so that (when $\left.V>D e b t_{s}\right)$ issuing $D_{A P}\left(=V-D e b t_{S}\right)$ dilution shares to Junior divides the firm according to the prespecified priorities.

Thus, returning to our analysis of how Junior's payoff changes with respect to its offers to buy (for fixed $D^{*}$ ), we find that:

$$
\frac{\partial \pi_{J}}{\partial B}\left\{\begin{array}{l}
>0, \text { when } D^{*}<D_{A P} \\
<0, \text { when } D^{*}>D_{A P}
\end{array}\right\} .
$$

This suggests that a nonstrategic Junior would offer to buy all of Senior's stock for dilution amounts less than $D_{A P}$ and offer to buy none of Senior's stock for dilution amounts greater than or equal to $D_{A P}$. Junior's nonstrategic bidding schedule $\left(B_{\text {Nonstrategic }}(D)\right)$ would thus be:

$$
B_{\text {Nonstrategic }}(D)=\left\{\begin{array}{l}
N_{S}, \text { when } D<D_{A P} \\
0, \text { when } D \geq D_{A P}
\end{array}\right\} .
$$

Conversely, a nonstrategic Senior would offer to sell none of its shares when $D<D_{A P}$ and would offer to sell all of its shares when $D \geq D_{A P^{:}}{ }^{56}$

$$
S_{\text {Nonstrategic }}(D)=\left\{\begin{array}{l}
0, \text { when } D<D_{A P} \\
N_{S}, \text { when } D \geq D_{A P}
\end{array}\right\} \text {. }
$$

For example, ignoring the potential strategic impact of sell offers on the amount of dilution, a nonstrategic seller would reason that when $D^{*}<D_{A P}$, the value of the marginal share $\left(V /\left(N_{s}+D^{*}\right)\right)$ is greater than $\$ 1$, so that it would be unprofitable to sell for a fixed price of $\$ 1$ per share. If Junior and Senior submit these nonstrategic bidding schedules, then the court would set $D^{*}=D_{A P}$, and no ancillary trades would be executed because $B\left(D^{*}=D_{A P}\right)=0$.

Strategic Juniors and Seniors would, however, consider how their bidding might affect the equilibrium level of dilution. A strategic Senior might want to raise its offers to sell (above zero, the nonstrategic supply) when $D<D_{A}$, in hopes of reducing the equilibrium quantity of dilution below $D_{A P}$. And a strategic Junior might want to raise its offers to buy

55. More generally, the level of dilution that implements the absolute priority rule (when zero shares are bought and sold in the ancillary executions) is:

$$
D_{A P}=\max \left[0, V-N_{S}\right] \text {. }
$$

56. A nonstrategic Junior or Senior is indifferent about how many shares it offers to buy or sell at $D_{A P}$ because at this amount of dilution it would be buying or selling stock that is intrinsically worth $\$ 1$ per share. 
(above zero, the nonstrategic demand) when $D>D_{A P}$, in hopes of increasing the equilibrium quantity of dilution above $D_{A P}$.

Strategic bidding of this kind, however, is not likely to be effective in changing the equilibrium level of dilution. First, consider the effect of strategic bidding by Junior in the part of its bidding schedule when $D>D_{A A^{*}}$. Even if Junior offered to buy all of Senior's shares $\left(N_{S}\right)$ for all $D>D_{A P}$, the equilibrium would remain at $D^{*}=D_{A P}$-because dilution stops when supply $(S(D))$ is greater than or equal to demand $(B(D))$. A strategic (or nonstrategic) Senior is sure to set $S\left(D_{A P}\right)=N_{S}$ to assure unilaterally that dilution will never exceed this amount.

Second, consider the effect of strategic bidding by Junior in the part of its bidding schedule in which $D<D_{A P}$. Remember (as shown in Equation 6) that either a strategic or nonstrategic Junior would offer to buy all of Senior's shares for these low amounts of dilution. Accordingly, only by offering to sell all of its shares could the seller reduce the equilibrium dilution amount below $D_{A P^{2}}$. But selling all of its shares would be completely ineffective in increasing Senior's payoff. The only way to reduce dilution is for Senior to sell the entire firm to Junior-which yields Senior the same return as $D^{*}=D_{A P}$.

Indeed, it is a Nash equilibrium for even strategic Juniors and Seniors to submit nonstrategic bidding schedules. ${ }^{57}$ Given that each player's opponent is submitting a nonstrategic bidding schedule, there is no alternative strategic schedule that will increase its payoff. ${ }^{58}$ The nonstrategic bidding schedule implements the absolute priority rule. If $V \leq D e b t_{s}$, then $D^{*}=0$ (and $B^{*}=0$ ), and Senior is awarded all the claims on the reorganized firm. If $V>D e b t_{s}$, then $D^{*}=D_{A P}=V-D e b t_{s}$ (and $B^{*}=0$ ), which effectively gives Senior stock with a value equal to the debt it is owed (Debt $\left.t_{s}=N_{s} \times \$ 1\right)$ and gives Junior the residual value $\left(V-\right.$ Debt $\left._{S}=D_{A P} \times \$ 1\right)$.

The nonstrategic bidding, however, is not a unique Nash equilibrium. For example, when $V>D_{e b t_{s}}$, it is also a Nash equilibrium for $B(D)=S(D)=N_{S}$ for all $D \geq 0$. Such bidding schedules would produce $D^{*}=0$ and $B^{*}=N_{s}$-so that in this equilibrium there would be no dilution, but Junior would purchase the entire firm for a total price of $\operatorname{Debt}_{s}\left(=N_{s} \times \$ 1\right)$. Thus, while there are multiple Nash equilibria with

57. Simply put, a "Nash equilibrium" exists at a position in which no player in a game has an incentive to change her strategy given the strategies of the other players.

58. There are, however, alternative strategies that will produce equal payoffs. For example, if Junior submits $B_{\text {Nonstratgir }}(D)$, then Senior can earn equal profits by submitting $S(D)=N_{s}$ for all $D$. As discussed below, see infra text accompanying note 59, this alternative equilibrium also implements the absolute priority rule. 
varying amounts of dilution $\left(D^{*}\right)$ and ancillary trades $\left(B^{*}\right)$, it is easy to see that every equilibrium will fully implement the absolute priority rule. ${ }^{59}$

The mechanism robustly assures that absolute priority will be observed because each claimant can unilaterally assure that it never receives anything less than what it is entitled to per the absolute priority rule. The willingness of Senior to sell all of its shares when $D \geq D_{A P}$ assures that Senior can never earn less than its absolute priority payoff. And the willingness of Junior to buy all of Senior's shares when $D<D_{A P}$ assures that Junior will never earn less than its absolute priority payoff. If each player's unilateral action can assure that it will not earn less than what it is entitled to under the absolute priority rule, then the players' actions together must robustly implement absolute priority. If $V<D e b t_{s}$, the unique equilibrium will be for Senior to offer all of its shares for sale $\left(S(D=0)=N_{s}\right)$, causing $D^{*}=0$ - and for Junior to offer to buy none of Senior's shares $(B(D=0)=0)$, causing $B^{*}=0$. In accordance with absolute priority, Senior will be given the only ownership in the reorganized firm. If $V>D e b t_{s}$, Senior, by bidding $S(D)=N_{s}$ for all $D \geq D_{A P}$, assures that $\pi_{s} \geq D e b t_{s}$, and Junior, by bidding $B(D)=N_{s}$ for all $D<D_{A P}$, assures that $\pi_{j} \geq V-D e b t_{s}$.

Because this is a zero-sum game in which the total payoffs must sum to $V$, these inequalities assure that absolute priority will be maintained: $\pi_{s}=D e b t_{s}$, and $\pi_{j}=V-$ Debt $_{s}$. There is thus a robust tendency in this simple model (when the claimants have sufficient liquidity and information) for the senior dilution mechanism to adhere to the creditors' contractual priority.

Indeed, this result can be characterized even more strongly. Not only is there no Nash equilibrium that violates absolute priority, but there is no disequilibrium (consistent with rational behavior) that violates absolute priority either. The robustness of the equilibria observing absolute priority

59. All possible Nash equilibria are depicted by the solid line in Figure 2. One part of the set (the horizontal portion) concerns equilibria in which the amount of dilution is less than $D_{A P}$, but in which Senior sells all of its $N_{S}$ shares. The other part of the set (the vertical portion) concerns equilibria in which the amount of dilution equals $D_{A P}$, but in which Senior sells some percentage of its $N_{s}$ shares.

Figure 2. Set of Nash Equilibria UndER The Dilution MEChanisM

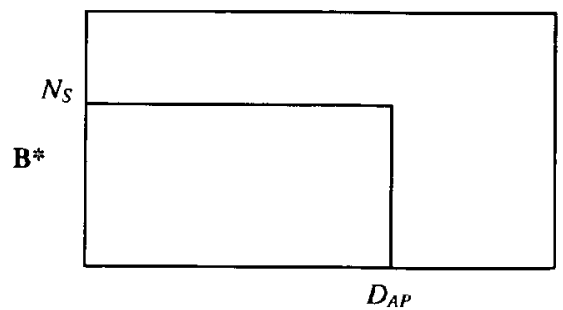

$\mathbf{D}^{*}$ 
does not turn on a player's belief about the other player's rationality nor on a player's belief about how the other player will bid. ${ }^{60}$ Absolute priority will result unless a party irrationally plays a dominated strategy. ${ }^{61}$ For example, if Senior refused to sell its shares even at a very high level of dilution $\left(D>D_{A P}\right)$, then Senior would receive less than the full value of the claim that it is due under the absolute priority rule. But as previously shown, a nonstrategic Senior would want to offer all of its shares for sale when $D \geq D_{A P}$ regardless of its beliefs about Junior's bidding strategy and regardless of the impact of Senior's own bidding on the equilibrium amount of dilution. The dilution mechanism therefore only requires a modicum of individualized player rationality to induce equilibria that comply with the absolute priority rule. Put another way, expressing greed for shares in this fixed-price game is self-defeating.

In the next Part, we show how the two-player results extend to the addition of several players. We will then discuss how absolute priority fares as we relax our informational and liquidity assumptions.

\section{EXTENDING THE MODEL}

\section{A. Adding Players per Class, Classes, and Third-Party Bidders}

Additional players might be added to the "game" in three different ways. There might be multiple players per class (that is, multiple senior or junior claimants), multiple priority classes (for example, senior, intermediate, and junior priority claimants), or third-party bidders (that is, nonclaimants who nonetheless submit bidding schedules to buy or sell at the fixed price conditional on dilution). This Section shows that the dilution mechanism can be easily extended to accommodate these additional player types and that absolute priority continues to be a robust equilibrium.

\section{Multiple Players per Class}

When there are multiple claimants per class, each claimant has an opportunity to submit a bidding schedule. And again the court would aggregate the bidding schedules to determine when supply was greater than or equal to demand. The primary difficulty that arises in considering

60. In some games, the stability of an equilibrium turns crucially on the rationality of each player being common knowledge. See Ian Ayres \& Barry J. Nalebuff, Common Knowledge as a Barrier to Negotiation, 44 UCLA L. REV. 1631, 1640 (1997).

61. For an example of a disequilibrium that occurs from strategies that are not dominated, consider a game in which $A$ and $B$ get to divide $\$ 1$ but only if each simultaneously submits the same distribution scheme. Otherwise, neither gets anything. $A$ and $B$ might each claim $\$ 0.90$ in the hope that the other will anticipate its greed and claim only $\$ 0.10$. 
multiple claimants within a class is to determine how many shares might be offered for purchase or for sale. For example, if junior claimants who were owed small amounts could each offer to buy all of the senior claimants' shares $\left(N_{s}\right)$, then it would be possible for the total demand at a particular level of dilution to be several multiples of the potential supply. We might worry that multiple junior claimants would collude to generate an artificially high demand-knowing full well that the supply of shares offered would be less ${ }^{62}$-in order to increase artificially the amount of dilution.

Policymakers could respond to this threat by limiting junior claimants to offering to buy only a pro-rata share of the senior claims. Under this limitation, if a junior claimant owed $12 \%$ of the junior claims, it would be limited to offering to purchase $12 \%$ of $N_{s}$. Limiting juniors to pro-rata purchases would suffice to protect them from the risk of under-dilution. Even at $D^{*}=0$, as long as a $12 \%$ junior claimant could effectively buy $12 \%$ of the reorganized firm, it could assure itself of the appropriate residual payoff $\left(\left(V-D e b t_{s}\right) \times 12 \%\right)$.

But we can do even better by changing the dilution-stopping rule. Instead of diluting up to the point at which supply $(S(D))$ is greater than or equal to demand $(B(D))$, we could simply say that dilution continues until supply is greater than or equal to either demand $(B(D))$ or potential supply $\left(N_{s}\right)$. Put algebraically:

$$
D^{*}=\underset{D}{\arg \min } S(D) \geq \min \left[N_{S}, B(D)\right] .
$$

Changing the dilution rule eliminates the ability of junior claimants strategically to inflate the equilibrium dilution amount by creating artificial demand greater than the potential supply. ${ }^{63}$ This new dilution rule makes it so that dilution will not necessarily continue even if juniors agree to buy more than $N_{s}$ shares, as seniors offering to sell all of their shares can still unilaterally cut off further dilution. ${ }^{64}$

62. One might think that senior claimants could artificially inflate their supply of shares above $N_{s}$ by offering short sales of shares. In thin markets, however, it is unlikely that short sales would be feasible.

63. The ancillary trade rule would also need to be modified so that:

$$
B^{*}=\min \left[N_{s}, B\left(D^{*}\right)\right]
$$

in which the offers to purchase are fulfilled on a pro-rata basis when $B^{*}<B\left(D^{*}\right)$. Offers to sell by multiple seniors are also fulfilled on a pro-rata basis when $S\left(D^{*}\right)>B^{*}$.

64. There is also concern that individual senior claimants cannot protect themselves under either of the dilution stopping rules. Imagine that Senior, believes correctly that $D_{A P}=0$ and offers to sell all of its fifty shares for any $D$. Senior, wrongly believes that $D_{A P}=20$ and refuses to sell its fifty until $D=20$. Juniors offer to buy seventy shares for $D<20$ and offer to buy zero for $D=20$. Under either of our stopping rules $D^{*}=20$ (because this is the minimum $D$ for which

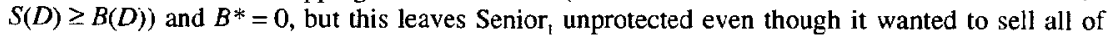


Allowing some juniors to bid more than their pro-rata shares of senior claims mitigates a potential problem of junior illiquidity. If some junior claimants are liquidity-constrained, then they may not have sufficient ability to demand their pro-rata share of senior claims when dilution is below the absolute priority amount $\left(D_{A P}\right){ }^{65}$ Allowing more liquid juniors to offer to purchase more than their pro-rata share mitigates the potential liquidity problem for other juniors by raising the aggregate demand for shares and hence the likely amount of equilibrium dilution.

Most important, having multiple players per class mitigates the likelihood of strategic bidding by seniors (to affect the equilibrium amount of dilution). A senior bidding strategically incurs the costs of expected bidding but not all of the benefits from the strategic bidding. The cost to a senior of artificially increasing its demand when dilution is low is the risk of selling shares that it values more than $\$ 1$. This cost is borne exclusively by the strategic bidders, but the benefits of artificially making the equilibrium dilution amount fall short of the absolute priority level flow to strategic and nonstrategic class members alike. Thus, even if strategic bidding were profitable for particular bidders as a class, there would be a tendency of individual bidders to want to free-ride on the efforts of others. For example, individual seniors will want their fellow class members to inflate their bidding schedules strategically in hopes of choking off dilution below the absolute priority level, while they individually maintain their low- $D$ offers to sell down toward a nonstrategic level (zero). Here is a circumstance where free-riding within the bidding classes conduces to intergroup efficiency. We will return to this free-riding effect when we consider more fully the problem of junior illiquidity. ${ }^{66}$

\section{Multiple Priority Classes}

To show how the model can be extended to multiple priority classes, this Subsection presents an example with three players-Senior, Intermediate, and Junior-who have successively more junior claims equaling $D e b t_{s}, D e b t_{,}$, and $D e b t_{j}{ }^{67}$ respectively. The amount of dilution will

its stock at $D=0$. We can come arbitrarily close to solving this problem by requiring $S(D)$ and $B(D)$ to be continuous. This would assure that $S^{*}=B^{*}$ and that Senior, would be protected. We would allow arbitrarily steep bidding schedules as long as they were still continuous. Thus, we would be requiring Senior ${ }_{2}$ continuously to increase its offers to sell somewhere near twenty and requiring the buyer continuously to decrease its offers to buy somewhere near twenty. This would come arbitrarily close to assuring that Senior ${ }_{1}$ would be able to sell all of its shares for $\$ 1$, and Senior $_{2}$ and Junior would be able to sell and buy some number of shares arbitrarily close to their indifference point of $D=20$.

65. See infra text accompanying note 73 .

66. See infra Section IV.C.

67. Instead, we could have as easily defined a senior class of creditors, a junior class of creditors, and an equity class. See supra note 53. 
again be determined by the point on the bidding schedules at which the supply equals or exceeds the demand (at a fixed price of $\$ 1$ ), but because there are three priority classes, some of the dilution shares may go to Intermediate, and some of the dilution shares may go to Junior. Just as we set $N_{s}=D e b t_{s} / \$ 1$, let us define $N_{l}=D e b t_{l} / \$ 1$.

Under the mechanism, the court gives $N_{s}$ to Senior, and if any dilution shares are issued, the next $N_{1}$ dilution shares are issued to Intermediate and any remaining dilution shares go to Junior. The players may offer to sell any shares that they will own (conditional on $D$ ), so that:

$$
\begin{aligned}
& S_{s}(D) \leq N_{s} \\
& S_{l}(D) \leq \min \left[D, N_{l}\right] \\
& S_{J}(D) \leq \max \left[0, D-N_{l}\right] .
\end{aligned}
$$

The players may offer to buy any outstanding shares (conditional on $D$ ) that are not their own:

$$
\begin{aligned}
& B_{s}(D) \leq D \\
& B_{l}(D) \leq N_{s}+\max \left[0, D-N_{l}\right] \\
& B_{J}(D) \leq N_{s}+\min \left[D, N_{l}\right] .
\end{aligned}
$$

The court aggregates the bidding and selling schedules and dilutes until the net demand is zero or negative:

$$
D^{*}=\underset{D}{\arg \min } \sum_{i} S_{i}(D) \geq \sum_{i} B_{i}(D)
$$

(in which the $i$ sum over the three priority classes). The dilution shares $\left(D^{*}\right)$ are divided between Intermediate and Junior according to the following equations:

$$
\begin{aligned}
& D_{,}^{*}=\min \left[D^{*}, N_{l}\right] . \\
& D^{*}=\max \left[0, D^{*}-N_{l}\right] .
\end{aligned}
$$

It is straightforward to verify that this mechanism, like the two-player mechanism discussed above, will produce equilibria consistent with absolute priority. ${ }^{68}$ When $V<D e b t_{s}$, Senior will offer to sell all of its shares

68. Under current practice, bankruptcy reorganization may bypass an intermediate class of creditor claims or equity interests while awarding property to more senior and more junior classes, all arguably consistent with absolute priority. Imagine, for example, that a debtor subject to $\$ 100$ in senior debt and $\$ 100$ in junior debt is worth $\$ 100$ if reorganized with the participation of pre- 
and Junior and Intermediate will offer to buy no shares, and $D^{*}=0$. When $D e b t_{s}<V<D e b t_{s}+D e b t_{l}$, Junior and Intermediate will offer to buy all possible shares up until $D=V-D e b t_{s}$, and Senior will offer to sell all of its shares for dilution greater than this amount. And finally, when $D e b t_{s}+D e b t_{1}<V$, Junior will offer to buy all possible shares up until $D=V-D e b t_{s}-D e b t_{l}$, and Senior and Intermediate will offer to sell all of their shares for dilution greater than this amount.

\section{Third-Party Bidders}

Third-party bidders are quintessentially nonstrategic because their bidding will not be influenced by the prospect of receiving either dilution $\left(D^{*}\right)$ or nondilution $\left(N_{s}\right)$ shares free of charge. Third-party participants add liquidity and information to the market and thus should only tend to make the mechanism work more efficiently. For example, if third parties believe that $V>D e b t_{s}$, then their bidding schedules are likely to push demand above supply for low $D$ and assure that junior claimants receive some shares even if the junior claimants themselves do not have sufficient information or liquidity to make nonrescindable offers to buy.

Third-party short sales can also be accommodated easily. As with their long purchases, third parties have no strategic incentive for offering to sell

bankruptcy shareholders, who are also managers with specialized human capital, but worth only $\$ 50$ without such participation. A consensual reorganization plan might provide the senior creditor an interest worth $\$ 80$, the junior creditor an interest worth $\$ 5$ (10 obrain the junior's consent), and the shareholders an interest worth $\$ 15$. This plan might seem a breach of absolute priority because the junior claims are not paid in full while shareholders receive property under the plan (indeed. more than the junior creditor). In fact, however, the plan represents a compromise among the classes of claims and interests, primarily between the senior creditor, who is entitled to the entire value of the firm absent the shareholders' participation, and the shareholders, who are not obligated to participate. The Bankruptcy Code permits the confirmation of such a plan as part of the bankruptcy reorganization process. 11 U.S.C. $\$ 1129$ (1994); see also supra note 22 (describing the process).

The dilution mechanism we propose in this Article makes no provision for such an arrangement among the classes. Under our mechanism, the shareholders would not expect to receive any continuing interest in the reorganized debtor unless both the senior creditor and the junior creditor are paid in full, an event that will not occur in this example. But this is not necessarily a shortcoming of our mechanism. Current bankruptcy reorganization combines a structured negotiation process among classes, as illustrated in the prior paragraph, with a valuation device when such negotiation fails. Our dilution mechanism is meant as a substitute for the latter only. Indeed, the plan described in the prior paragraph can be confirmed in current practice only if the junior creditor consents to the shareholders' continuing interest. With such consent, no judicial valuation is necessary, and the dilution mechanism similarly would be unnecessary. Absent such consent, moreover, either current bankruptcy practice (to the extent it honors absolute priority) or the dilution mechanism would operate to award the entire interest in the debtor to the senior creditor. In either case, the senior creditor might be able to strike a subsequent side deal with the former sharcholders for their continuing participation. (The results would be similar if the debtor were worth less than the amount of the senior claim without shareholder participation but between the amount of the senior claim and the total debt obligation with shareholder participation.) Part $\mathrm{V}$ further discusses how a dilution mechanism can substitute narrowly for the judicial valuation component of current bankruptcy reorganization practice. 
short, and evidence that third parties are willing to sell shares short again provides a thicker market of both information and liquidity to ascertain the underlying value of the firm. ${ }^{69}$

In sum, the tendency of the model to produce absolute priority equilibria continues to be quite robust, even when multiple parties are added. The addition of multiple priority classes leaves the prior analysis unaffected, while the addition of multiple players to a class or the addition of third-party bidders actually strengthens the results. Multiple players added to a class create a free-riding effect that reduces the likelihood that individual players will bid strategically, while the nonstrategic bids of third parties add liquidity and will tend to swamp any attempts of preexisting claimants to inflate or deflate the equilibrium amount of dilution artificially.

\section{B. Heterogeneous Valuations}

The foregoing analysis has assumed that claimants of the firm agree that the firm is worth a certain value $(V)$, which is common knowledge. If we relax this homogeneous valuation assumption, there are a number of alternative possibilities that might be considered. For example, we could consider the divergent valuations of just two players (Senior and Junior), or we might admit divergent valuations of multiple players within each priority class. Alternatively, the heterogeneous valuations of the individual claimants might be commonly known, or the claimants might have a certain amount of private information about their individual valuations.

While the particular type of value heterogeneity and the particular types of claimant knowledge about others' valuations will affect the claimants' strategies and the ultimate dilution equilibrium, the possibility of either heterogeneous values or heterogeneous information - in any of its varied forms-does not undermine the strong tendency of the senior dilution mechanism to comport with the demands of absolute priority.

The central idea here is one of self-protection. As long as junior claimants have sufficient liquidity, each individual claimant will continue to have the ability to assure unilaterally that it receives by its own lights a payoff at least as large as it would be owed if absolute priority were observed. Stated more formally:

For any estimate that any given claimant has of $V$, the senior dilution mechanism will provide the claimant with a payoff that does not fall below the payoff to which the participant is entitled

69. Short sales of a unitary Senior would not be necessary to shut off dilution (as our revised rule would stop dilution whenever $S(D)=N_{s}$ ). Short sale offers when there are multiple sellers might be undertaken for strategic reasons, but because of free-riding, short sales are more likely to represent sincere beliefs about the relative value of the firm. 
under the absolute priority rule using the claimant's own estimate of value. ${ }^{70}$

Regardless of whether the other claimants place higher or lower values on the firm, and regardless of whether the valuations of the other claimants are perfectly or imperfectly known, each claimant has the unilateral ability to assure that its payoff at least yields what-given its own value of the firm-it is entitled to under the absolute priority rule. This is not to say that no claimant will ever make a mistake in its valuation of a firm and thus receive less than absolute priority requires. But all estimation is inherently uncertain, and no process aimed at absolute priority can do better than assuring each participant its own version of such priority.

For example, an individual senior claimant can assure itself of at least its absolute priority payoff by offering in its bidding schedule to sell all of its shares (its pro-rata portion of $N_{s}$ ) if dilution exceeds what it believesgiven its own assessment of the firm's overall value-is the amount of dilution that would implement the absolute priority rule. Likewise, an individual junior claimant can assure itself of at least its absolute priority payoff by offering to purchase its pro-rata portion of the senior claimants' shares when dilution falls short of what it believes to be the absolute priority level. ${ }^{71}$

70. This self-protection attribute of the dilution mechanism is also an attribute of Bebchuk's option approach and was originally (and insightfully) formulated by Bebchuk. See Bebchuk, supra note 6, at 788-97.

Eric Talley pointed out that this self-protection attribute might need to be modified in circumstances where one claimant's valuation might be affected by its beliefs about other claimants' valuations. For example, if a junior and a senior claimart's valuations are imperfectly - but positively — correlated, then the junior claimant's willingness to buy might be a function of the senior claimant's willingness to sell. If the players under the dilution mechanism have to submit bidding schedules simultaneously, a junior may, because of the "winner's curse" effect, shade down its demand. But of course, just as the junior may be less willing to buy if the senior is willing to sell, the senior may be less willing to sell if the junior is willing to buy, and the senior will similarly adjust its bidding schedule. Just as winner's curse corrections under standard auction assumptions yield sale prices that are an unbiased estimate of underlying value, we believe it plausible to assume that the dilution process would yield results that are an unbiased estimate of absolute priority.

71. If an individual junior claimant owns a fraction $j$ of the total junior claims, it must offer to buy the same fraction $j$ of the senior shares $\left(j \times N_{s}\right)$. To see this, imagine that the junior believes the firm to be worth more than the outstanding senior debt $\left(V>D e b t_{s}=N_{s}\right)$ so that under the absolute priority rule, the junior claimant based on its own valuation of the firm is entitled to a "payoff of $\left(V-N_{s}\right)(j)$. To guarantee this amount, the junior claimant must submit a bidding schedule that yields this payoff for every possible amount of dilution:

$$
\left(V-N_{S}\right) j=\frac{j D+B(D)}{N_{S}+D} V-B(D) .
$$

This equation can be solved for $B(D)$ to find the amount that a junior claimant would need to bid for various levels of dilution to assure a payoff equal to or greater than the amount it is owed according to the absolute priority rule. The equation simplifies to $B(D)=j \times N_{s}$, which proves that for any level of dilution, a junior claimant only needs to offer to buy its proportionate share of the senior shares in order to protect itself. 
Absent liquidity problems (to be discussed in the next Section), each claimant can unilaterally assure itself at least a payoff equal to what, based on its own beliefs, it is due under the absolute priority rule. Because such absolute priority payoffs for every claimant are feasible independent of the strategies of other players, each player must, in expectation, receive at least this much in equilibrium. ${ }^{72}$ Heterogeneous valuations and heterogeneous information thus pose no difficulty for the ability of the dilution mechanism to implement absolute priority.

\section{Ameliorating the Problem of Junior Illiquidity}

Illiquidity is a much more serious concern. If junior claimants do not have sufficient money to buy at least their proportionate interest of the senior shares, then junior claimants will not be able to assure themselves of receiving a payoff consistent with absolute priority. Illiquidity of senior claimants is not a concern because they do not need to offer to buy in order to protect themselves. But junior claimants do-and we have even suggested that they be required to post a sufficient bond so that a court can be assured of executing their nonrescindable offers to buy in their bidding schedules. Junior illiquidity may allow senior claimants to reduce strategically the equilibrium amount of dilution below the amount that is consistent with the absolute priority rule (without having to adopt the selfdefeating strategy of selling all of their shares to junior claimants).

The temptation for strategic senior claimants to inflate their offers to sell in their bidding schedule when $D$ is low (in hopes of reducing the equilibrium amount of dilution) is particularly great because seniors will

Moreover, the dilution mechanism could both permit each junior to bid for more than its prorata share and require continuous bidding schedules that could be arbitrarily steep. This combination would permit juniors who value the debtor's shares more than others to purchase more of those shares. See supra note 64.

72. Assume, for instance, that there is one senior and one junior claimant. When the senior claimant values the firm more than does the junior claimant (or if each claimant only imperfectly knows the other's valuation), there may be some potential for strategic bidding. For example, if $D e b t_{s}=N_{s}=100$, and the senior claimant believes the firm to be worth $140\left(=V_{s}\right)$ while the junjor claimant believes the firm to be worth only $120(=V$ s), then nonstrategic bidding would induce (1) the senior claimant to offer to sell nothing until $D=40$, and (2) the junior claimant to offer to buy all of the senior shares until $D=20$. Such nonstrategic bidding would be favorable to the senior, with $D^{*}=20$ and $B^{*}=0$. But a junior claimant knowing (or even having imperfect information) that the senior claimant had a higher valuation might be tempted to increase its offers to buy for $20<D<40$, in hopes of inflating the equilibrium amount of $D$ toward 40 (and the senior claimant, foreseeing this, might inflate its offers to sell in hopes of keeping the equilibrium amount of $D$ down toward 20 ). When the senior claimant values the firm more than the junior claimant, there is a kind of surplus value over which the parties can haggle, because by the junior claimant's lights its absolute priority share of the firm is smaller than the amount it is due by the senior claimant's lights. But as stressed in the text, there cannot be an equilibrium at which any claimant accepts a lower expected payoff than the amount consistent with absolute priority that it could have assured itself by unilateral action. 
only have to sell as many shares as the potentially illiquid junior claimants offer to buy. In a two-person game, even if the senior claimant thinks there is only a chance that the junior claimant may be illiquid, it has incentives to offer to sell all its shares in its bidding schedule when $D=0$. If the junior claimant is not liquidity-constrained and offers to buy all of the senior's shares when there is no dilution, the senior will receive what it is due under the absolute priority rule. But if the junior turns out to be liquidityconstrained, the senior will only have to sell as many shares as the junior can afford to buy-and thus will retain some number of shares worth more than $\$ 1$ per share. This result is troubling because it suggests that when junior claimants are illiquid, the dilution mechanism may systematically deviate from the absolute priority rule in ways that give too much of the reorganized firm to the senior creditors.

There are four factors, however, that will work to ameliorate this illiquidity problem. To save time, we will refer to these, respectively, as "third-party bidding," "dilution leverage," "free-riding," and "acquiescence" effects, which either individually or in combination can work to push the claimants' equilibrium payoffs toward those that comport more with the absolute priority rule, even when junior claimants have insufficient liquidity to assure this result independently.

\section{Third-Party Bidding}

First and foremost, there is the possibility that third parties (nonclaimants) will submit bidding schedules offering to buy senior's shares when dilution is below the absolute priority amount or lend money to junior claimants so that they can increase their own offers. Third-party liquidity is thus a straightforward palliative for junior illiquidity. The added liquidity of third-party bidders and lenders is tremendously important as an empirical matter, but old hat as far as theory. Thick (liquid) markets will do a better job-with less opportunity for strategic manipulation-than thin (illiquid) markets. And as mentioned above ${ }^{73}$ allowing individual junior claimants to purchase more than their pro-rata shares of senior claims in effect turns individual juniors into third parties, increasing the demand for senior shares. The extra liquidity of particular claimants can thus make up for the relative illiquidity of their junior claimant siblings.

\section{Leveraging Dilution Shares}

Even when junior claimants as a group are insufficiently liquid to offer to purchase all the senior shares, the dilution mechanism may also allow

73. See supra text accompanying note 65 . 
junior claimants to leverage the value of their dilution shares to increase their effective liquidity. Imagine, for example, that third-party lenders are imperfectly informed about the reorganized firm's value and are accordingly unwilling to lend junior claimants sufficient funds to purchase all of the senior shares. The amount that junior claimants will be able to borrow should be a function of their personal assets and how much they can convince a bank and other third parties that the firm is worth. For higher levels of dilution $(D)$, junior claimants can pledge more assets as security for the loan because they can also pledge their dilution shares and hence should be able to bid more.

For example, imagine that an imperfectly informed bank believes the firm is only worth some percentage $(L)$ of what the claimants correctly believe the firm to be worth $(V)$. Also imagine that the bank demands a $100 \%$ securitization, so that it will lend no more than the assets that junior claimants can offer. The junior securitizing assets may take one of three forms: (1) independent assets $(A)$ that the junior claimants may have, (2) (the bank's beliefs about) the value of senior stock that juniors propose to buy (as emphasized above, however, these assets may not provide full securitization by themselves, given the bank's beliefs about the firm's value), and (3) (the bank's beliefs about) the value of dilution shares that the junior claimants are about to receive. While the amount of equilibrium dilution is not known ex ante, the bank can make the amount that it is willing to lend conditional on the amount of ultimate dilution. With these assumptions, the most that junior claimants can offer to buy in their bidding schedule will be the $B_{\operatorname{MAX}}$ that solves the following equation for various levels of dilution:

$$
B_{M A X}\left[1-\frac{L V}{N_{S}+D}\right]=A+\frac{D L V}{N_{S}+D} .
$$

The left-hand side of the equation represents the amount of collateral that the juniors would need to provide to a lender if they wanted to borrow enough money to purchase $B_{\text {MAX }}$ senior shares. The right-hand side of the equation shows the two sources of collateral that juniors can potentially offer: their independent assets and the value of their dilution shares.

Solving this equation for $B_{\text {MAX }}$ yields:

$$
B_{M A X}=\frac{A N_{S}+D(A+L V)}{N_{S}+D-L V} .
$$

By taking the derivative of this equation with respect to $D$, it can be shown that the maximum amount that the juniors can offer to buy in their bidding schedules will increase as $D$ increases when the purchased shares and the 
juniors' independent assets are not sufficient security to buy all of the senior claimants' shares $\left(N_{s}>L V+A\right)$.

This means that the junior claimants' ability to pay may increase as dilution increases - even though their willingness to pay will decrease for sufficiently high dilution amounts. Figure 3 , for example, plots the junior claimants' optimal bidding schedule when one assumes that $D e b t_{S}=D e b t_{j}=100, V=150, A=10$, but $L V=80$ (so that the last inequality holds). When $D=0, B_{M A X}=50$, but when $D=50, B_{\text {MAX }}=78.57$. For values of $D>50$ (the absolute priority level of dilution), the junior claimants would reduce their demand to zero-not because of an inability to purchase, but because of an unwillingness to purchase. This example shows that junior illiquidity is less likely to constrain the bidding schedule as $D$ increases. When illiquidity (i.e., inability to pay) is the binding constraint, we may therefore see, as shown in Figure 3, that the aggregate junior bidding schedule increases with $D$ for some interim levels of dilution before falling at the point at which dilution exceeds the absolute priority level $\left(D_{A P}\right)$. This means the illiquidity problem is largest for very low $D$-and is particularly worrisome when $D^{*}$ is equal to zero.

\section{FIGURE 3. EXAMPLE OF THE LEVERAGE EFFECT INCREASING ILLIQUID JUNIORS' ABILITY TO PURCHASE}

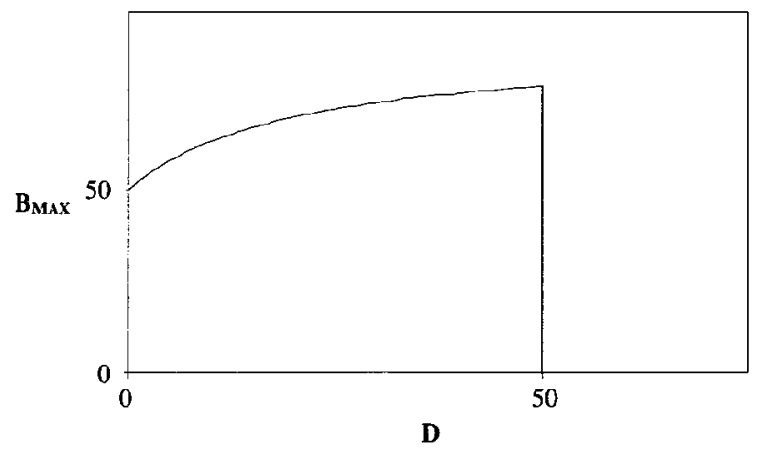

Even if third parties mistakenly think that the firm is worth less than the senior claimants' debt $\left(D e b t_{s}\right)$, they are still likely to be willing to lend money to leverage the limited preexisting assets of the junior claimants. For example, as shown in Figure 3, if third parties mistakenly believe that the firm is worth only $\$ 80$, while senior debt is $\$ 100$, a junior claimant with just $\$ 10$ may be able to bid for up to half of the senior claimants' shares when dilution is zero and borrow even more to submit higher bids as the level of potential dilution increases.

This leveraging effect will never completely eliminate the liquidity problem, even at high levels of dilution. A third-party bank that refuses to 
lend sufficient funds to buy the firm (by purchasing all of the seniors' shares) when dilution is nil will not be willing to lend such a sum just because junior claimants have some dilution shares to pledge. But the foregoing example and Figure 3 show that a third-party bank may be willing to lend more to a diluted firm when the dilution shares are pledged as additional security for the loan.

The facially counterintuitive willingness of junior claimants to offer to buy more shares at a fixed price of $\$ 1$ per share as dilution increases is strong evidence that illiquidity was constraining their offers to purchase at lower levels of dilution. And, as it turns out, the courts can modify the dilution mechanism to take advantage of this information and further ameliorate the illiquidity problem. Instead of simply setting the dilution level at the lowest amount for which supply is equal to or greater than demand, the court would do better first to set dilution at the highest level for which supply equals demand. If there are no such levels at which supply and demand are equal, only then should it resort to setting dilution at the lowest level at which supply exceeds demand. ${ }^{74}$ Consider, for example, how this revised mechanism would work if the junior claimants submitted the bidding schedule shown in Figure 3, while the senior claimants submitted a schedule that offered to sell seventy shares for $D<50$ and offered to sell all of their 100 shares for $D \geq 50 .^{75}$ These bidding schedules are shown in Figure 4. Under the original stopping rule, the court would set the equilibrium amount of dilution at zero (as this is the lowest level for which supply (seventy) is greater than demand (fifty)). But under the revised rule, the court would set the equilibrium level of dilution equal to twenty, as being the highest level at which supply equals demand. And at this level, the juniors would be able to purchase seventy of the senior claimants' shares, giving the juniors a payoff of $\$ 42.50$-still below their absolute priority desert of $\$ 50$, but substantially above the $\$ 25$ they would have received under the original stopping rule.

74. This modification would most likely be implemented together with the earlier-discussed requirement of submitting continuous bidding schedules. See supra note 64 . Requiring continuity would prevent a strategic bidder from avoiding equal bidding amounts by submitting idiosyncratic and discontinuous bids for higher dilution levels.

75. As explained in the next Subsection, free-riding by multiple senior claimants may restrict their ability to makc strategic offers to sell some of their shares when the dilution amount is low. 
FIgURE 4. EXAMPLE OF A REVISED MECHANISM INCREASING THE EQUILIBRIUM LEVEL OF DILUTION IN ORDER TO AMELIORATE JUNIOR ILLIQUIDITY

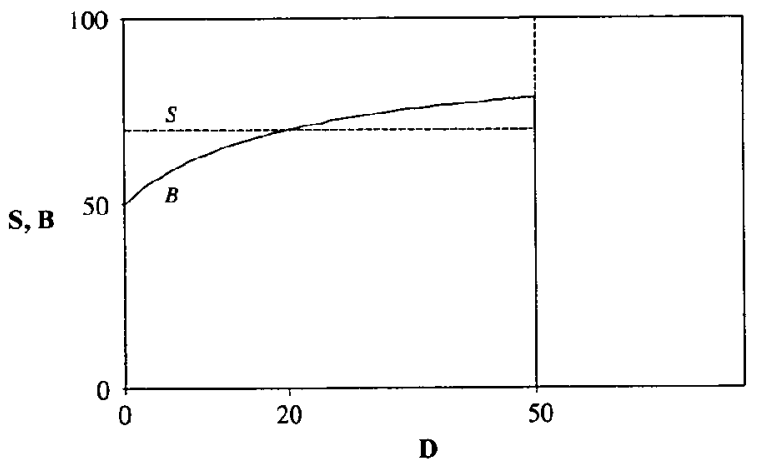

Moreover, if we imposed a requirement that bidders cannot discontinuously increase or decrease their bidding schedules, ${ }^{76}$ the equilibrium level of dilution could rise close to the absolute priority level of $\$ 50$ as being the highest point at which the demand and supply curves cross. At this amount of dilution, the junior would receive a payoff arbitrarily close to its absolute priority desert of $\$ 50$.

While this modification seems complicated, it merely asks the court to look to see, before implementing the original dilution rule, whether there are any higher dilution amounts for which demand equals supply. Because the senior claimants can completely protect themselves by offering to sell their shares for higher levels of dilution, this pro-dilution modification does not undermine the senior claimants' ability to assure themselves an absolute priority payoff, and it gives the junior claimants a better opportunity to overcome the potential problem of illiquidity.

\section{Free-Riding}

In addition to third-party bidding and lending, two other factors will tend to undermine the ability of the senior claimants to inflate their bids strategically in order to take advantage of junior illiquidity. We refer to these effects as "free-riding" and "acquiescence."

As mentioned above, when there are multiple senior claimants, they may have difficulty coordinating a strategy of inflated offers to sell at low dilution amounts. This happens in large part because overbidding imposes costs on the senior claimants who overbid but produces benefits for all the senior claimants. If a senior claimant does not think that its offers to sell

76. See supra note 64 . 
will be pivotal in causing the total sell offers to exceed the illiquid buy offers, then it will want to reduce its offers to sell. From the perspective of an individual senior claimant, it would be better to have the other senior claimants sell their shares to shut off dilution, as that individual would retain a greater portion of initially issued shares.

Even in a world with perfect information about junior illiquidity, it may be difficult for seniors to coordinate their bidding schedules to shut off dilution. For example, imagine that there are just two senior claimants, each of whom is owed \$50. It is common knowledge among these claimants that the firm is worth $\$ 150$ and that the junior claimants in their bidding schedules will only be able to offer to buy one-half of the senior shares when $D=0$ (as in Figure 3). There are many Nash equilibria to this game that violate the absolute priority rule. For example, it would be a Nash equilibrium for each senior claimant to offer to sell twenty-five of its shares when $D=0$. Neither senior claimant would want to deviate from such a proposed strategy, because offering twenty-five shares is pivotal to shutting off dilution. ${ }^{77}$ But it would also be a Nash equilibrium for the senior claimants to offer to sell thirty and twenty shares, respectively, or two and forty-eight shares, respectively. Any combination of sell offers exactly equaling the commonly known amount that the junior can offer to buy would be a Nash equilibrium with zero dilution - and would represent the maximal liquidity-induced deviation from absolute priority.

But there are good reasons to think that multiple senior claimants may have difficulty coordinating to "find" one of these Nash equilibria. There may not be a simple enough focal point to suggest that one of these pure strategy equilibria dominates the others-especially if there are more than two senior claimants and if they are owed asymmetric amounts. ${ }^{78}$ Thus, even if the seniors know how much the junior claimants can spend, they may not be able to agree on pivot strategies that will allow them to deviate maximally from their absolute priority payoffs.

This coordination problem becomes much more severe when the senior claimants are only imperfectly informed about the degree of junior illiquidity. When senior claimants are unsure how much money the junior claimants have to spend (after visiting their banks), then it will be difficult for them to coordinate offering to sell sufficient shares to cut off dilution at a small amount. Each individual senior claimant will have an incentive to reduce the number of shares that it offers to sell because there will be some

77. Both players offering to sell all their shares when $D=0$ would not be a Nash equilibrium because neither of the players' bids would be pivotal. If one senior claimant believed that the other was going to offer all fifty of its shares, the first senior claimant would do better to reduce its offer to zero.

78. Any mixed strategy equilibrium would be dominated by a pure strategy equilibrium. We therefore ignore mixed strategies. 
probability that such shares will prove not to be pivotal in shutting off dilution.

Consider the stylized example in which there are two senior claimants who are each owed $\$ 50$ confronting a single junior claimant who has an ability to pay when $D=0$ that is uniformly distributed somewhere between $\$ 0$ and $\$ 100$. Assume that among the claimants, it is common knowledge that the firm is worth $\$ 200$, but that neither the court nor third parties know this for sure (and that third parties are unwilling to bid or lend money to assist junior bidding). Finally, to simplify the analysis, assume that the court has decided that it will set dilution either at zero or 100 sharesdepending on whether there are excess offers to buy at the lower dilution amount. $^{79}$

In this example, the senior claimants would maximize their combined expected payoffs (at the expense of the junior claimant) by submitting bidding schedules offering to sell all of their shares when $D=0$. Such bids would assure that there would be no dilution in equilibrium and that they would each sell half of whatever the junior claimant had funds to buy. Each senior claimant would consequently retain an equal number of shares worth $\$ 2$ per share. If the seniors submitted such bids, the junior would have a payoff of only $\$ 50$ (whereas under absolute priority it is due $\$ 100$ ), and the seniors together would have a combined expected payoff of $\$ 150-\$ 50$ greater than their absolute priority desert. ${ }^{80}$ The senior claimants' uncertainty about the junior's illiquidity, however, means that bidding these inflated amounts would not be an equilibrium strategy. Instead, in this stylized example, it can be shown that in equilibrium each of the individual senior claimants will offer to sell only 33.33 shares when $D=0 .{ }^{81}$ The

79. Constraining the equilibrium level of dilution to discontinuous amounts reduces the players' strategy space to a two-dimensional vector (instead of a continuous function of the dilution amount). This assumption is somewhat analogous to baseball arbitration in which the disputants submit discontinuous alternative offers, and the arbitrator picks one or the other. As in baseball, arbitration that gives the court a dichotomous and discontinuous choice may further serve to discipline the senior claimants' bidding. See Amy Farmer \& Paul Pecorino, Bargaining with Informative Offers: An Analysis of Final-Offer Arbitration, 27 J. LEGAL STUD. 415, 415-16 (1998). But as noted above, see supra note 64, discontinuous bidding schedules may have the detriment of undermining the self-protection benefit when claimants have heterogeneous valuations.

80. The junior claimant on average will have $\$ 50$ to bid when $D=0$. It will thus buy on average fifty shares worth $\$ 2$ per share for a price of $\$ 1$ per share-earning an expected value of $\$ 50(=50 \times(\$ 2-\$ 1))$. The senior claimants must then on average carn the residual value of the firm, $\$ 150(=\$ 200-\$ 50)$.

81. The expected payoff for an individual senior claimant, as a function of both its and the other senior claimant's offers to sell $S$, and $S_{2}$, respectively, when dilution is zero, is:

$$
\pi_{S_{1}}=\frac{\left(S_{1}+S_{2}\right)}{100}\left(100-\frac{S_{1}}{2}\right)-\frac{\left(1-S_{1}-S_{2}\right)}{100}(50)
$$

The first term on the right-hand side of the equation represents the probability that equilibrium dilution will equal zero multiplied by the senior claimant's expected payoff if this occurs; the 
symmetric equilibrium that satisfies the corresponding first-order condition for the other senior claimant produces an equilibrium in which $S_{1}=S_{2}=S=100 / 3$. These equilibrium strategies will not assure zero dilution, and the expected payoff of the junior claimant will increase to $\$ 72.22$ - still below its absolute priority desert of $\$ 100$ but substantially above what would occur if there were a single senior claimant.

The example shows that when senior claimants are uncertain about the degree of junior illiquidity, each will tend to free-ride on the others' dilution efforts by reducing the amount that it offers to sell in the portion of its bidding schedule when the potential amount of dilution is low. While free-riding is normally associated with inefficient outcomes, free-riding by seniors attempting to collude to violate the absolute priority rules improves social efficiency. Moreover, this beneficial free-riding effect is enhanced as either the uncertainty or the number of senior claimants increases. In sharp contrast, the presence of multiple juniors does not lead to an analogous type of junior free-riding. An individual junior has an independent, nonstrategic incentive to bid to buy as much of the senior claimants' shares as it can for portions of its bidding schedule in which dilution is below the absolute priority level $\left(D_{A P}\right)$.

In sum, even when the bidding of junior claimants and third parties fails to bring sufficient liquidity to the market, the free-riding of multiple senior claimants can ameliorate some of the worst problems of under-dilution. ${ }^{82}$ Particularly when there is some uncertainty about the degree of the junior claimants' illiquidity, it will be extremely difficult for the senior claimants to coordinate bids in which each player's offer to sell is pivotal to shutting off the dilution. If each senior claimant believes that it can reduce its sell offers without substantially lowering the equilibrium level of dilution, then each claimant will perceive its bids to be nonpivotal and hence be more likely to free-ride. Failing to find pivotal bidding strategies will tend to reduce the senior claimants' equilibrium offers to sell and thus increase the equilibrium level of dilution toward a level that better comports with absolute priority.

second term on the right-hand side represents the probability that dilution will equal 100 shares multiplied by the senior claimant's expected payoff if this occurs. Taking the derivative of this expected payoff with respect to $S_{i}$ and setting the expression equal to zero yields the traditional Coumot first-order condition:

$$
100-2 S_{1}-S_{2}=0 .
$$

82. The beneficial effects of senior free-riding are, however, contingent on the senior claimants being sufficiently numerous. In many bankruptcies, the claims of at least some senior classes will be relatively concentrated in the hands of a relatively small number of creditors, such as secured lenders. 


\section{Acquiescence}

Finally, the problem of junior illiquidity may be ameliorated if the reorganized firm will be more valuable if junior claimants retain control or at least sufficiently substantial share ownership to give appropriate agency incentives. We refer to this as an "acquiescence" effect because there are times when senior creditors will acquiesce in the juniors' dilution of their shares-even though the juniors' illiquidity might have allowed the seniors to fend off dilution.

To capture the possibility that the reorganized firm may be worth more if the stock remains controlled by the junior claimants, imagine that it is common knowledge among the claimants that the reorganized firm will be worth $\$ 80$ if the junior claimants do not own a majority of the stock $\left(V_{N J}=\$ 80\right)$, but that the reorganized firm will be worth $\$ 120$ if the juniors continue to own a majority of the stock $\left(V_{J}=\$ 120\right)$. To emphasize how acquiescence can ameliorate the problem of junior illiquidity, we assume it is common knowledge that the junior claimants have only $\$ 40$ to spend to buy shares (with no prospect of third-party bidding or lending). And to distinguish this acquiescence effect from the aforementioned free-riding, we assume that there is only a single senior claimant (who is owed $\$ 100$ ).

With these assumptions, it is easy to see what would happen if the senior claimant chose to submit a bidding schedule with an offer to sell more than forty of its shares when $D=0$. The liquidity-constrained junior would not offer to buy any shares, because it would not be able to attain majority ownership and hence would be paying $\$ 1$ for something that would ultimately only have a value of $\$ 0.80$. We might therefore consider a possible equilibrium in which the senior offered to sell all of its shares, and the liquidity-constrained junior offered to buy none of its shares when $D=0$. Such bidding would produce a potential equilibrium in which there was no dilution $\left(D^{*}=0\right)$ and in which there was no ancillary trade $\left(B^{*}=0\right)$. Because the junior claimants would own none of the reorganized shares, the total value of the reorganized firm would be only $\$ 80$ - and all of this value would accrue to the senior claimant.

However, while such bidding is an equilibrium, it is dominated by another equilibrium in which the senior creditor can do better by acquiescing in some dilution of its ownership in order to take advantage of the added value that comes from giving the junior claimants majority ownership in the firm. If the senior creditor instead submitted a nonstrategic bidding schedule that offered to sell none of its shares when $D<20$ and offered to sell all its shares for $D \geq 20$, it is possible to produce an equilibrium in which $D=D^{*}=20$, and the junior claimants would purchase forty shares of the senior claimant's stock at a fixed price of $\$ 1$ per share 
$\left(B^{*}=40\right){ }^{83}$ In this equilibrium, the junior claimants would end up with fifty percent of the outstanding shares (twenty dilution shares plus forty purchased shares out of a total of 120 issued shares), and the total firm value would be 120 . But in contrast with the zero-dilution equilibrium that only yielded an $\$ 80$ payoff for the senior claimant, the twenty-share dilution equilibrium gives the senior claimant its absolute priority payoff of $\$ 100$ - as the senior claimant ends up owning half the shares in a firm worth $\$ 120$ and receives an additional $\$ 40$ for selling some of its initial shares $(\$ 60+\$ 40=\$ 100)$. Moreover, the acquiescence effect moves the junior claimants' payoff closer to what it deserves under the absolute priority rule as well. Instead of receiving $\$ 0$ under the zero-dilution equilibrium, the junior claimants now earn their absolute priority payoff of $\$ 20$-as they end up owning half the shares in a firm worth $\$ 120$, but had to pay $\$ 40$ for some of these shares $(\$ 60-\$ 40=\$ 20)$.

It is not cur claim that the acquiescence effect will always lead to exact implementation of the absolute priority rule whenever substantial junior ownership of stock increases the expected value of the reorganized firm. The fact that it did in the foregoing example is merely an artifact of the numbers that we chose. But it is our claim that value added by junior claimants will tend to result in an acquiescence effect that will ameliorate the strategic incentive for the seniors to infiate their bids in order to cut off share dilution below the absolute priority level ${ }^{84}$

The existence of this acquiescence effect does not hinge on the junior claimants' belief that the firm's value will be "out of the money" if the junior claimants fail ultimately to control the firm. For example, imagine that everything is as before ( $D e b t_{s}=\$ 100$; the junior claimants' ability to pay is $\$ 40$ ), but imagine that it is also common knowledge among the claimants that the reorganized firm will be worth $\$ 110$ if the junior claimants do not own a majority of the stock $\left(V_{N J}=\$ 110\right)$ and worth $\$ 150$ if the juniors continue to own a majority of the stock $\left(V_{s}=\$ 150\right)$. Under these alternative "in the money" valuation assumptions, it will now be in each junior claimant's nonspeculative interest to offer to use all of its limited liquidity to buy as much of the senior claimants' shares as it can regardless of whether that junior claimant believes that the junior claimants will end up owning a majority of the reorganized firm or not.

Again, it is useful to compare zero-share and twenty-share levels of dilution. If the senior claimants submitted bidding schedules offering to sell more than forty shares for $D=0$, then there would be (given the junior illiquidity) zero dilution shares issued, and the junior claimants would

83. For this to be an equilibrium, the junior claimants' bidding schedules would have to offer to buy a positive number of shares (say, forty) for all levels of dilution less than twenty.

84. Senior claimants might effectively acquiesce in junior control under alternative mechanisms by accepting nonvoting shares or debt claims in the reorganized firm. 
purchase forty shares $\left(B^{*}=40\right)$. Because the juniors would ultimately own only a minority of the outstanding stock $(40 \%)$, the total value of the reorganized firm would only be $\$ 110$; this value would be divided among the claimants such that the senior claimants would earn a payoff of $\$ 106$ and the junior claimants would earn a payoff of $\$ 4 .{ }^{85}$

It turns out, however, that this is not an equilibrium because each senior can unilaterally increase its payoffs by acquiescing to a limited amount of dilution. If a senior instead offers to sell none of its shares for $D<20$ and offers to sell forty of its shares when $D=20$, it can do even better by harnessing the added value of junior claimant control of the reorganized firm. This acquiescence bidding strategy produces an equilibrium with twenty dilution shares being issued $\left(D^{*}=20\right)$, and with forty shares being sold from the senior to the junior claimants $\left(B^{*}=40\right)$. In this acquiescence equilibrium, the junior claimants would again (as in the out-of-the-money example) end up with $50 \%$ of the outstanding shares (twenty dilution shares plus forty purchased shares out of a total of 120 issued shares), so that the total firm value would be $\$ 150$. And in contrast to the zero-dilution equilibrium that only yielded payoffs of $\$ 106$ and $\$ 4$ for the senior and junior claimants, respectively, the acquiescence equilibrium divides the value added so that the payoffs for the senior and junior claimants are, respectively, $\$ 115$ and $\$ 35^{86}$

Notice that in this example, senior acquiescence makes the senior claimants' payoff deviate even more from the $\$ 100$ they deserve under the absolute priority rule ( $\$ 115$ vs. $\$ 106)$. But in our minds, the acquiescence equilibrium is a movement toward absolute priority because of the almost nine-fold increase in the junior claimants' expected payoff. The $\$ 31$ increase in the junior payoff more than offsets the $\$ 9$ increase in the senior payoff. While under the absolute priority rule, the senior claimants are not due more than the amount of their original debt, the problem of junior illiquidity threatens to produce even more inefficient deviations from the absolute priority desert. And while our examples have turned on whether or not the junior claimants end up with a majority interest in the reorganized firm, the acquiescence effect can arise whenever some amount of junior stock ownership can increase the overall value of the firm.

This said, one might fairly wonder whether the dilution mechanism will, in fact, serve to protect an illiquid junior, because the senior could

85. The senior claimants end up owning sixty percent of a firm worth $\$ 110$ as well as $\$ 40$ earned by selling some of their initial shares $(0.6 \times \$ 110+\$ 40=\$ 106)$; the junior claimants end up owning forty percent of a firm worth $\$ 110$, but had to pay $\$ 40$ for these shares $(0.4 \times \$ 110-\$ 40=\$ 4)$.

86. The senior claimants end up owning half the shares in a firm worth $\$ 150$ and receive an additional $\$ 40$ for selling some of their initial shares, providing them with $\$ 115(=\$ 75+\$ 40)$. The junior claimants end up owning half the shares in a firm worth $\$ 150$, but had to pay $\$ 40$ for this privilege, providing them with $\$ 35(=\$ 75-\$ 40)$. 
choose to keep as many shares as possible at the lowest possible dilution and proceed to negotiate with the junior for a sale back of a controlling interest. When the transaction costs of such negotiation are high, however, the senior might choose instead to adjust its offer schedule to accomplish the acquiescence described here.

In sum, the potential illiquidity of junior claimants is the only important reason why the dilution mechanism might fail to implement the absolute priority rules. And we have not provided any silver-bullet fixes to eliminate this potential problem in all conceivable contexts. We have shown, however, that four different factors may importantly ameliorate the illiquidity problem and restrict the circumstances where it is a concern:

(1) Third-party liquidity can lubricate otherwise illiquid bidding;

(2) Leveraging the value of dilution shares can enhance third parties' willingness to lend (and may, with appropriate modifications to the dilution mechanism, support higher equilibrium levels of dilution);

(3) The free-riding of multiple senior claimants may undermine their attempts to overbid strategically; and

(4) Value added by substantial junior ownership in the reorganized firm may give senior claimants an incentive to acquiesce in the dilution of their own claims.

While we have analyzed these effects separately, they may be particularly effective in ameliorating junior illiquidity when they arise in combination. For example, the free-riding and acquiescence effects may deter seniors from submitting inflated offers to sell at very low levels of dilution, while concurrently, the leveraging effect may allow juniors to submit sufficiently high offers to purchase for intermediate-dilution portions of their bidding schedules. Together, these two effects would raise the equilibrium level of dilution, bringing it even further toward the absolute priority level.

\section{APPLYING THE “JUNIOR DILUTION" APPROACH IN CRAMDOWNS}

Whatever the theoretical appeal of the dilution mechanism, one might wonder whether the proposed process has any practical use. Senior dilution can, in principle, substitute for all aspects of the current bankruptcy process once that process identifies relative priorities. In other words, given senior dilution, bankruptcy need not include a process of negotiation among creditors, shareholders, and managers, or intervention of a judicial 
valuation-all of which comprise current law and practice. Theory aside, however, bankruptcy judges armed with the Bankruptcy Code's provision of a negotiation and settlement mechanism are unlikely to abandon that process entirely. Nevertheless, under current law, a "junior" version of the dilution mechanism proposed here permits a bankruptcy judge to continue the current bankruptcy practice of structured negotiation until and unless the parties reach an impasse, at which point our mechanism, rather than judicial valuation, can settle matters. As described in Part II, when a structured negotiation among a corporate debtor's constituents succeeds only partially, a bankruptcy court may be called on to confirm a reorganization plan over the dissent of one or more classes of claims, and such confirmation is called a "cramdown." LaSalle, discussed in Part $\mathrm{II}^{87}$ involved the dissent of a class that objected, as a doctrinal matter, to equity's proposed take in the reorganization rather than to its own. But in another common cramdown scenario, the class or classes that dissent from a proposed plan are senior claims whose holders contend simply that the plan would not pay these claims in full.

Imagine that a debtor's pre-bankruptcy equity owners (and managers), along with the debtor's junior creditors, propose a reorganization plan to divide the debtor's new equity among themselves and to provide the debtor's pre-bankruptcy senior claims with new debt obligations that the plan proponents contend are worth the amount of the senior claims. For example, assume that the aggregate senior claim and the aggregate junior claim are for $\$ 100$ each. The reorganization plan seeks to compensate the seniors with a new loan with a $\$ 100$ face amount and a specified interest rate. ${ }^{88}$ The senior creditors object on the ground that, in their estimation, the new loan is not worth $\$ 100$. This is, in essence, an argument that the new loan's interest rate is too low. ${ }^{89}$ Consistent with absolute priority, section 1129 (b) of the Bankruptcy Code permits the court to confirm the plan over the seniors' objection only if the court is satisfied that the new obligation would in fact be worth $\$ 100,,^{90}$ a determination that requires the court not only to value the firm, but also to estimate the variance of that value, which will in turn affect the value of any new debt obligation. (All else being equal, the riskier the debtor, the less valuable the debt.) The court is left

87. See supra text accompanying notes 16-19.

88. Under bankruptcy law, a secured claim would become a senior claim for our purposes based on judicial valuation of collateral under section 506 (a) of the Bankruptcy Code, 11 U.S.C. $\$$ 506(a) (1994), a relatively simple process as compared with the valuation of a going concern. See supra note 51 .

89. Of course, if the reorganized firm is worth less than the amount owed to senior claimants, no interest rate may be high enough to provide seniors payment in full.

90. Section 1129(b) contains additional requirements for confirmation, none of which are particularly relevant to this discussion. 11 U.S.C. $\$ 1129(b)(1994)$. 
with a number of imponderables. As one bankruptcy judge put it in In re Pinebrook, Ltd.:11

An appropriate interest rate should be calculated on a case by case basis, considering such factors as the prevailing market rate for a loan of equal term to that proposed in the debtor's plan, the quality of [any] collateral securing the [new] indebtedness, the credit standard of the borrower, and risk of subsequent default. ${ }^{92}$

As we discussed in Part II, such judicial valuation can be inaccurate, biased in favor of plan proponents (even if the judges themselves are unbiased), and expensive measured in both direct and indirect costs. Market alternatives do not suffer from all of these defects.

This is not the entire story, however. Although judicial valuation of a going concern may be inefficient, there are potential advantages to other aspects of the bankruptcy reorganization process. A primary benefit of current bankruptcy practice, according to its supporters such as Judge Bufford, ${ }^{93}$ is that the process permits the holders of junior interests to retain those interests, if they are entitled to do so, under supervision of the bankruptcy court rather than through unsupervised negotiations between juniors and seniors-all despite both the juniors' own illiquidity and the absence of a robust outside market. ${ }^{94}$ This is particularly important when, as is sometimes the case, continued participation in the debtor's business by holders of the junior interests is essential to an effective reorganization. ${ }^{95}$ In any case, regardless of whether judicially supervised bankruptcy does in fact have advantages over a pure market alternative, under current practice, debtors in bankruptcy will find themselves enmeshed in a judicial process and not subject to a pure market alternative.

The dilution mechanism we propose here permits the bankruptcy process to benefit from the best of both worlds. In the illustration immediately above, the current bankruptcy reorganization process could proceed to the point that judicial valuation in cramdown now occurs. Consistent with the spirit of LaSalle, however, and within the court's

91. 85 B.R. 160 (Bankr. M.D. Fla. 1988).

92. Id. at 162 .

93. See supra notes $25-31$ and accompanying text.

94. We use the term "junior interest" here because, in this Part, we introduce the use of a dilution mechanism that includes equity holders. In our above discussion of senior dilution, we limited our examples to senior and junior creditor classes, and thus referred to "junior claims." In bankruptcy parlance, a "claim" refers to a debt obligation, while an "interest" refers to a shareholder's rights. Nomenclature aside, however, the distinction is unimportant, and either senior or junior dilution works with classes of claims or interests. Thus, throughout this Article, in our discussion of either junior or senior dilution, the reader may treat "junior claims" and "junior interests" as interchangeable.

95. See Baird \& Rasmussen, supra note 11. 
discretion under current law, ${ }^{96}$ the bankruptcy judge could substitute our dilution mechanism for a valuation hearing. The dilution mechanism is well-tailored to answer the single question of whether the dissenters' senior claims would be paid in full under the plan. If the answer was yes, the court would confirm the plan. Otherwise, the junior claims and interests would be eliminated. This process could be completed in a single, fixed-price auction and would not depend on the number of, or varying priority among, the different senior classes that dissented, as the plan would not be viable under the Bankruptcy Code unless all of the seniors were paid in full (as priority is irrelevant among claims to be paid in full). For the purposes of the dilution mechanism, then, all senior claims of dissenting classes could be aggregated into a single senior stratum. In sum, the dilution mechanism would replace judicial discretion only on the issue of adherence to absolute priority-an adherence that the Bankruptcy Code, as interpreted by the Supreme Court, demands. The rest of the bankruptcy reorganization process could remain unaffected, as we explain more fully below.

\section{A. Inside-Bidders Application}

A fixed-price auction "junior" variant of the senior dilution mechanism we analyzed above neatly meets the demands of a market valuation within the context of current reorganization law. To see this, consider a debtor corporation that files for bankruptcy while subject to $\$ 100$ in debt. The debtor's managers argue that the debtor is in fact solvent and propose a reorganization plan that would provide the creditors with $\$ 100$ of new debt. The pre-bankruptcy shareholders-principally the managers themselveswould receive the reorganized firm's equity. The creditors object to this plan, arguing that the debtor is worth less than $\$ 100$ and that they should receive the entire firm. Absolute priority dictates that the plan proponents should retain the debtor's equity interest if the proponents' valuation is correct, but not otherwise. In this context, a market valuation would test the parties' competing valuations, but would not displace the plan itself in the event that the plan passes the test. To accomplish such a test, we propose a "junior dilution" mechanism that conceptually or actually auctions the new debt obligations at a fixed price-set as above so that the fixed price multiplied by the number of outstanding debt obligations equals the amount of debt outstanding (here, $\$ 100$ ). As in the original senior dilution mechanism, bidders would be asked to submit a schedule. Each schedule would indicate the bidder's demand for the new debt obligations at various

96. See 11 U.S.C. \$1 105(a) (1994) ("The court may issue any order, process, or judgment that is necessary or appropriate to carry out the provisions of this title."). 
interest rates, including the interest rate proposed in the plan. ${ }^{97}$ Also, as in the original dilution mechanism, each senior, who would receive the bonds upon confirmation of the plan, could be asked about its willingness to sell at these various rates.

We refer to this method as our "junior dilution" mechanism. While our original senior dilution mechanism potentially diluted the value of senior claims (by raising the proportion of free cash flow dedicated to junior claims), our junior dilution mechanism potentially dilutes the value of the proponents' junior claims (by raising the proportion of free cash flow dedicated to senior claims). Put more prosaically, reorganized shares will own a smaller fraction of the reorganized firm's total value if the interest on the new debt is increased. The court again aggregates the bidding schedules, but now, instead of setting the amount of dilution at the lowest level at which supply for shares equals or exceeds demand, the court sets the interest rate at the lowest rate at which demand for debt exceeds or equals supply. At this equilibrium interest rate, the court, in confirming the plan, would execute the number of bids to sell-the short side of the market-instead of executing the number of bids to buy under the original dilution mechanism. ${ }^{98}$

To see the junior dilution mechanism in action, assume, for example, that the debtor in this illustration is, in fact, worth more than $\$ 100$ so that at some interest rate bonds with a face amount of $\$ 100$ are worth $\$ 100$. To arrive at this interest rate-call it $I_{A P}$ (which is analogous to $D_{A P}$ in the model above) - a court could employ the following process. The shareholder plan proponents and creditor opponents could be required to bid and ask, respectively, for the sale of bonds with a total face amount of $\$ 100$ across a schedule of interest rates. At interest rates below $I_{A P}$, the bonds are worth less than their fixed price, so fully informed shareholders would not offer to buy while fully informed creditors would offer to sell. At interest rates above $I_{A P}$, the bonds are worth more than their fixed price, so fully informed and liquid shareholders would bid to buy, but, given shareholder liquidity, no fully informed creditor would offer to sell the bonds. Thus, this mechanism could yield a nonstrategic equilibrium with an interest rate on the new bonds set properly at $I_{A P}$, the point at which offers vanish and bids

97. A fixed-price auction could also be implemented by varying other aspects of the bonds auctioned. For example, bidders might be asked how many bonds they would want to buy or sell at $\$ 100$ apiece when the amount of assets securing the bonds was varied.

98. More formally, under a junior dilution model, the court after aggregating the bidding schedules would confirm the plan with an equilibrium rate of interest $I^{*}$ equaling:

$$
I^{*}=\underset{I}{\arg \min } B(I) \geq S(I)
$$

and simultaneously would execute the sale of $S\left(I^{*}\right)$ debt securities from seniors to juniors. 
appear. No bonds need actually change hands. ${ }^{99}$ The court could thus confirm the reorganization plan at this equilibrium interest rate that honors absolute priority. This equilibrium rate might be the initial proposed interest rate, if the proponents are borne out and that rate happens to be $I_{A P}$, or the fixed-price auction might suggest that a higher rate is appropriate. But in either case, the mechanism should tend to divide the firm in conformity with the absolute priority rule. Only if the proponents were wrong, and the reorganized firm was worth less than $\$ 100$, would the plan fail outright, as in that case $I_{A P}$ would be infinite and the conditions for confirmation could not be satisfied. ${ }^{100}$

Assume, for example, that the debtor's value in this illustration is $\$ 150$ based on a $50 \%$ chance that the debtor will be worth $\$ 75$ and a $50 \%$ chance that the debtor will be worth $\$ 225 .{ }^{101}$ Under these conditions, a $\$ 100$ face obligation issued by this debtor would be worth $\$ 100$ if the interest rate were $25 \%$. That is, if the debtor issued a $\$ 100$ note with a promise of $\$ 25$ in interest, the holder of this note would expect the entire $\$ 75$ value of the debtor if the debtor had a poor outcome (a $50 \%$ probability) and $\$ 125$, principal and interest, if the debtor had a good outcome (also a $50 \%$ probability). The expected value of such an outcome is $\$ 100 .{ }^{102}$ Under our junior dilution mechanism, in which the price of the note is fixed at $\$ 100$, one would expect supply but no demand for a $\$ 100$ note when $I<25 \%$, and one would expect demand but no supply for a $\$ 100$ note when $I>25 \%$. In other words, here $I_{A P}=25 \%$, and the court could confirm a reorganization plan that included the issuance of a $\$ 100$ note at that interest rate. A

99. The careful reader will recognize that under the sterile conditions of this illustration, the number of bonds with an interest rate of $I_{A P}$ bought in equilibrium can range from zero to all the bonds issued, given that at $I_{A P}$, the bonds are worth exactly their fixed price. $C f$. supra note 56 (describing the analogous set of equilibria implementing absolute priority under the senior dilution mechanism). In theory at least, plan proponents who seek to hold only equity (and not a mixture of equity and bonds) could still limit dilution without needing actually to purchase the new debt via the mechanism of ancillary trades. This is so because the proponents can assure this outcome, at a cost approaching zero, by failing to bid for any bonds at $I_{A P}$, and by bidding for all of the bonds at an interest rate above, yet arbitrarily close to, $I_{A^{*}}$. In any case, the real world fact of heterogeneous value estimations makes precise ties that yield utter indifference as unlikely as balancing a pea on the edge of a knife.

100. Even when the reorganized firm is worth more than the senior's absolute priority claim, there might not be an interest rate at which supply equals demand. For example, if excess leverage creates large agency costs, see Stuart C. Gilson et al., Troubled Debt Restructurings: An Empirical Study of Private Reorganization of Firms in Default, in BANKRUPTCY AND DisTRESSED RESTRUCTURINGS 77 (Edward I. Altman ed., 1993); Joseph E. Stiglitz \& Andrew Weiss, Credit Rationing in Markets with Imperfect Information, 71 AM. ECON. REV. 393, 393-94 (1981), then it is possible that a senior dilution mechanism of an all-equity firm would indicate that the firm was worth more than the senior's claim, while a junior dilution mechanism would fail to find a noninfinite level of dilution. But this problem is limited by the size of the agency costs, which in turn is limited by the amount of debt in a proposed reorganization.

101. $(0.5 \times \$ 75+0.5 \times \$ 225)=\$ 150$. For this calculation and those that follow we ignore, for simplicity, both the passage of time and the role of investor risk aversion. No important result would change were we to relax these assumptions.

102. $(0.5 \times \$ 75+0.5 \times \$ 125)=\$ 100$. 
creditor owed $\$ 100$ who received such a note would be paid in full, consistent with absolute priority, notwithstanding the plan's distribution to holders of junior interests.

Now, change the facts of this illustration so that the debtor is worth $\$ 90$ based on a $50 \%$ chance that the debtor will be worth $\$ 75$ and a $50 \%$ chance that the debtor will be worth $\$ 105 .{ }^{103}$ Under these conditions, a $\$ 100$ face obligation issued by the debtor even with an infinite interest rate would be worth less than $\$ 100$, as the entire value of the debtor is less than $\$ 100$. Under our dilution mechanism, one would expect supply but no demand regardless of the interest rate. In other words, here $I_{A P}$ is infinite. The court could not confirm any plan under which an interest junior to the creditors received any property. This result also comports with absolute priority.

The implications of this illustration, moreover, are robust. Recall that, as required by absolute priority under the Bankruptcy Code, any dissenting class of creditors is entitled either to full satisfaction of its claims or to the entire residual value of the debtor firm once any senior claims have been satisfied. ${ }^{104}$ Other than in the context of new-value contributions at issue in LaSalle, once priority is determined, it is self-evident whether a dissenting class is receiving the entire residual value of a debtor firm; one need observe only whether the plan provides any property to a lower-priority class. Thus, in any cramdown case not complicated by a new-value contribution, the only difficult question is whether the dissenting class or classes are to be fully compensated. If there is more than one dissenting class, the relative priority among those classes becomes irrelevant, as the plan cannot be confirmed unless every dissenting class is paid in full. Consequently, a court could employ junior dilution just as in the above illustration by aggregating the claims of every dissenting class, regardless of relative priority. ${ }^{105}$ The process would be simple. We recognize that these happy conditions for absolute priority do not universally apply. In the real world, there may be both heterogeneous valuations and junior illiquidity. With the senior dilution mechanism, the concern of junior illiquidity is that seniors would cut off dilution of their claims too soon by strategically offering to sell more of their shares. With junior dilution, the concern of junior illiquidity is that seniors will allow dilution of junior claims to continue too long by strategically offering to sell more of their debt.

103. $(0.5 \times \$ 75+0.5 \times \$ 105)=\$ 90$.

104. This description is somewhat impressionistic. For a more precise account, see supra note 22 and accompanying text.

105. This is not to say that the dilution mechanism could not work with multiple priority classes. It could. See supra Subsection IV.A.2. Although one could modify the junior dilution mechanism to address multiple priority classes, outside the context of current bankruptcy reorganization practice, discussed in the text, there would be no need to do so, as, freed from current practice, one could simply deploy senior dilution. 
Our previous analysis of senior dilution, however, also suggests ways that junior dilution can respond to these concerns. For example, heterogeneous valuations once again pose no obstacle to our junior dilution mechanism, which provides each participant the autonomy to hold, sell, or buy according to its own estimates of value. Indeed, although we have referred here to our dilution approach as a market-valuation device, at least where liquidity is not a concern, the process we propose is in a sense superior to a valuation by outside market participants, as each participant can rely on the junior dilution mechanism to award it a return at least as large as what it owned under absolute priority - given its own idiosyncratic valuation of the firm.

We explained, moreover, how third-party liquidity, free-riding, leverage, and acquiescence can mitigate a junior-liquidity problem. These explanations apply here as well. Some of the terms change, but the concepts do not. For example, to establish an interest rate above $I_{A P}$, the seniors as a group must offer to sell more bonds than demanded at that interest rate, but individually have an incentive to hold their shares and free-ride on others. ${ }^{106}$ Similarly, at lower interest rates, the shares that the juniors hold are more valuable and serve as better collateral for a loan that can provide greater liquidity. ${ }^{107}$ Finally, it is easy to see that junior dilution can also accommodate an acquiescence effect when junior control adds valuesimply because the mechanism, by varying the interest rate on debt, does not affect the juniors' $100 \%$ ownership of equity.

\section{B. Third-Party Bidders Application}

The role of third parties in a solution to the junior-liquidity problem is particularly important in the context of this mechanism and the LaSalle

106. Imagine that two seniors are each owed $\$ 50$ and that a junior only has $\$ 50$ in liquidity. The two seniors have a strategic incentive to collude to offer to sell more than fifty bonds (at a fixed price of $\$ 1$ ) for interest rates greater than $I_{A P}$-in order to raise the equilibrium interest rate and excessively dilute the junior's claim. For example, imagine that the two seniors agree to offer to sell all their bonds until $I=2\left(I_{A P}\right)$, and then to reduce their supply to zero. If the seniors perform on this agreement, the equilibrium interest rate is likely to be twice the absolute priority amount. But free-riding is now a rcal risk. Each senior should worry that the other will chisel on the collusive agreement by reducing its offer to sell at a lower interest rate. The senior who fails to chisel ends up selling all of its bonds at par and thus makes no excessive interest. As before, freeriding among a relatively small number of senior claimants might undermine the strategic incentive to inflate the aggregate supply schedule.

107. Indeed, the leveraging effect is even stronger at low levels of dilution with junior dilution than with the previously analyzed senior dilution depicted in Figures 3-4, supra Subsection IV.C.2. In the extreme, under a mechanism of junior dilution in which the juniors propose a reorganization plan with a zero interest rate, the juniors have for low levels of dilution ( $I$ close to zero) claims to almost all of the firm's assets (cash flow) to pledge as collateral for bank loans. Therefore, the leveraging effect is strongest at low levels of dilution (low $I$ ) under junior dilution, while the previous analysis suggested that the leveraging effect would be strongest at high levels of dilution (high $D$ ) under a senior dilution mechanism. 
mandate that courts employ market tests. The mechanism could work within current reorganization law and, given third-party liquidity ${ }^{108}$ without the seemingly-though only seemingly-radical addition of simultaneous schedule exchanges among holders of claims and interests. A court that wanted to test a reorganization plan over class objection could simply auction the disputed property on the market. This auction would be ordinary in all respects except that the currency of the bids, which would be fixed for all bids, would be the interest rate instead of cash. The lowest interest rate bids, if any, would win. In the current illustration, at some interest rate, the new debt with a face amount of $\$ 100$ would all be purchased for $\$ 100$. The bankruptcy court would then issue the new debt at the lowest interest rate that would clear the market and issue the debt to the purchasers. The plan proponents would retain the equity, just as their plan proposed. On these terms, the court would confirm the plan, which would be confirmed by all parties unless the debtor was, in fact, worth less than $\$ 100$, as bidders would not pay $\$ 100$ for the new debt even at an infinite interest rate. The low-interest bids, or lack thereof, would reveal the true valuation to the court, which would confirm only those plans consistent with absolute priority. Thus, this version of the dilution mechanism-one that dilutes the junior rather than the senior interest-can effectively test reorganization plans in a single auction procedure ${ }^{109}$ When the plan is, in fact, consistent with absolute priority, it will be confirmed without any further investment by the proponents or the need for the proponents to negotiate a continued interest in the firm with a purchaser. Otherwise, the plan will fail, as it should.

This fixed-price auction mechanism, moreover, is flexible. In the above illustration, the pre-bankruptcy shareholders are the plan proponents and argue that the debtor is solvent. But the mechanism would work as well for a plan proposed by, or on behalf of, junior creditors over the objection of senior creditors, including holders of secured claims. ${ }^{110}$ In each instance, the fixed-price auction mechanism tests whether there is enough value in a debtor to satisfy the claims of a senior claim despite the retention of property by a junior claim or interest, regardless of whether the comparison

108. There may be no appropriate market test for a cramdown when neither plan proponents nor third parties can provide liquidity. See Adler, supra note 20, at 20.

109. A traditional auction of new debt with a fixed interest rate proposed by the plan proponents and a reservation price of $\$ 100$ would not work as well as the fixed-price auction mechanism suggested here. Needless delay could result in a process that rejected a reorganization plan whenever an auction price of proposed compensation proved less than dissenting creditors' claims. Such a shortfall might be the result of insufficient value in the debtor, or it might be the result of a miscalculation by plan proponents. Thus the shortfall might or might not be eliminated by a subsequent auction of an enhanced compensation package. Rather than a process of repeated trial and error, a fixed-price auction with variable interest rates, as proposed here, allows for expedited results.

110. But see supra note 52 (discussing issues of collateral valuation). 
is between debt and equity, or senior and junior debt. Thus, the mechanism broadly permits a market valuation that augments, rather than replaces, bankruptcy reorganization under current law. In this way, the mechanism satisfies the Supreme Court's charge in LaSalle.

\section{COMPARISON WITH Alternative Proposals}

Current bankruptcy reorganization law and practice comprise a set of structured negotiations among holders of claims and interests in a debtor corporation. Structured negotiation can be costly, ${ }^{111}$ and it is not the only conceivable bankruptcy process. In this Part, we first explain three alternative mechanisms: Douglas Baird's full auction proposal, Mark Roe's partial-float proposal, and Lucian Bebchuk's option proposal. We provide a numerical example of how Bebchuk's option proposal works, as that is most relevant to our comparison. We then demonstrate how in thick markets, our junior dilution mechanism is preferable to Baird's and Bebchuk's proposals, as those proposals force junior claimants to incur additional transaction costs (whereas our proposal does not), and Roe's proposal, because of the risk of strategic manipulation and the possibility of skewed compensation if the slice represents the controlling interest in the firm. Finally, we depict how in thin markets, our proposal becomes even more advantageous than our peers' proposals, as the acquiescence and freeriding effects will help set the proper dilution equilibrium.

The simplest alternative is for a court to conduct a cash auction of a firm that seeks bankruptcy protection. Holders of the firm's pre-bankruptcy claims and interests would divide the proceeds of the auction. The highest bidder for the firm could continue the firm or liquidate it, as it saw fit. There could be problems assessing the relative priority of asset-based lenders, because serious bids might come in only for the firm as a whole, and not for particular assets that serve as collateral. But these problems might be relatively insignificant because the valuation of specific assets, which may often be fungible with assets traded elsewhere, could be a relatively simple matter when compared with the difficulty in the valuation of a firm as a going concern, ${ }^{112}$ the latter valuation being essential to a Chapter 11 determination of whether dissenting holders of claims or interests are to receive their due under a reorganization plan. Thus, the insolvent firm auction, an idea developed by and associated with Douglas Baird, ${ }^{113}$ provides a seemingly attractive alternative to bankruptcy reorganization.

111. See supra notes 21-23.

112. See supra note 52 (describing alternatives to judicial valuation of collateral).

113. Baird, supra note 4; Baird, supra note 15. 
There are other market-based alternatives. Mark Roe has suggested that bankruptcy law provide not for the sale of the entire firm, but for the sale of a small portion of all new interests in the firm. ${ }^{114}$ The purchase price from the sale of such a vertical slice would serve as the basis for the issuance of additional new interests in exchange for pre-bankruptcy claims and interests. A full-scale auction would be unnecessary.

Finally, Lucian Bebchuk has proposed a well-known option mechanism for valuing insolvent corporations. ${ }^{115}$ He proposes a bankruptcy process in which each holder of a claim or interest would be granted a conditional option, exercisable in ascending order of priority. The option would entitle the holder to buy a ratable portion of all higher priority claims or interests at face value unless a holder of a lower priority claim or interest exercised its option to purchase the holder's own claim or interest. If any set of options were exercised, the firm would emerge from this process subject to the new residual interest, or claims and interests, of those who so exercised their options. If no one exercised an option, the highest priority pre-bankruptcy claims ratably would share all new interests in and any claims against the firm.

To illustrate Bebchuk's proposal, assume that a bankrupt firm owes ten senior claimants $\$ 10$ each and ten junior claimants $\$ 10$ each and has ten preexisting shareholders with one share each. Also assume that the reorganized firm will be worth $\$ 150$ and that the court is trying to figure out how to distribute among the junior and senior claimants ten new equity shares (which, by hypothesis, are worth $\$ 15$ each). The court could issue ten new shares of the debtor to the holders of the senior claims, each of which would be subject to an option by a holder of a junior claim. The option held by each owner of a junior claim would, in turn, be subject to an option held by the holder of an old equity share. Each old equity owner could exercise its option to purchase a junior's option for $\$ 10$, then would have an option to buy a new equity share for another $\$ 10$. Presumably, no old equity owner would exercise its option, as it would cost each old equity owner $\$ 10$ to purchase an option to spend another $\$ 10$ to purchase a new share worth $\$ 15$, for a loss of $\$ 5$. After each old equity holder passed on its chance to exercise, each holder of a junior claim, by contrast, would have an incentive to exercise its option, as it could for $\$ 10$ purchase a new share worth $\$ 15$, for a gain of $\$ 5$. In the end, the senior creditors would receive payment in full, the junior creditors collectively would pay $\$ 100$ for a $\$ 150$ firm, and the old equity holders would be wiped out. This is what absolute priority requires. It follows that if the debtor were worth more than $\$ 200$,

114. Roe, supra note 5.

115. Bebchuk, supra note 6; see also Aghion et al., supra note 15 (incorporating Bebchuk's options approach into a broader reorganization framework). 
each old equity holder would exercise its option and an option purchased from a junior creditor, leaving the senior and junior creditors paid in full with the residual firm value to the old equity holders. On the other hand, if the debtor were worth less than $\$ 100$, no one would exercise any option, leaving the senior creditors with the entire value of the firm. These results also comport with absolute priority.

At heart, we view Bebchuk's proposal to be another market-dependent solution (like our own). An essential element to the Bebchuk proposal is that individual investors, who may not have the resources to exercise even a valuable option, could sell their options to a purchaser or purchasers with sufficient resources. When junior claimants are liquidity-constrained, Bebchuk's proposal requires them either to sell their options to the market or to negotiate with third-party lenders.

As a reorganization mechanism that honors absolute priority, each of these proposals for reform would work comparably well if all interested parties and potential capital sources were fungible, fully liquid, and fully informed. However, when the identity of an investor matters, or when investors face liquidity constraints in a world of limited information-that is, in the real world - the dilution mechanism we describe here has potential advantages over the alternatives.

This observation, expounded below, plays an important role in the reform debate. The major criticism that bankruptcy practitioners and others, including Judge Bufford, ${ }^{116}$ have leveled at past academic reform proposals is that academics fail to address the variance between reality and the academics' simplifying assumptions. These critics, whom Baird has labeled "traditionalists," believe that would-be reformers overlook what Baird calls "the richly textured complications that each case presents." 117 As we explained in Part V, our dilution mechanism both harnesses market forces to the extent possible and responds to the concerns of the traditionalists. We now explain why we believe our proposal is unique in this regard.

\section{A. Thick External Markets}

Consider a debtor corporation worth between $\$ 50$ and $\$ 150$ that is subject to $\$ 100$ in senior debt. The holders of the junior interest argue that the debtor is, in fact, worth more than $\$ 100$, while the holders of the senior interest argue that the debtor is worth less than $\$ 100$. Thus, in this classic valuation conflict, at least one of the claimarits seeks a larger portion of the reorganized firm's value than absolute priority would allow. The simplest solution to this controversy, of course, would be-à la Bebchuk-for the

116. See supra notes 25-31 and accompanying text.

117. Douglas G. Baird, Bankruptcy's Uncontested Axioms, 108 YALE L.J. 573, 593 (1998). 
juniors either to pay the seniors $\$ 100$ or to cede the firm. If the juniors lack personal capital, however, they may be unable to pay $\$ 100$, even if the true value of the debtor exceeds that amount.

The market reforms proposed by Baird, Roe, and Bebchuk might set matters straight if outside investors could easily evaluate the debtor. An outright sale of the debtor, or a slice thereof, could establish the debtor's true value, and cash or interests in the debtor could be distributed accordingly. Similarly, under Bebchuk's proposal, the juniors could attempt to sell or finance the exercise of their options. If the debtor's value is above $\$ 100$, and market investors know this, the juniors could raise the needed capital. As Judge Bufford might point out, however, none of these proposals takes into account the possibility that the value of the debtor is endogenous to the identity of the juniors as holders of the debtor's residual claim. This possibility is not necessarily fatal to these market reform proposals. The purchasers are free to negotiate with the juniors for the juniors' continued involvement in the debtor's affairs. Once such involvement is assured, the true value of the debtor can again drive the outcome of these market mechanisms. Keep in mind, though, Judge Bufford's statement that the market's failure to eliminate these very transaction costs justifies bankruptcy itself.

The junior dilution mechanism, unlike the other market alternatives, allows third party liquidity to value the firm without requiring an additional negotiation to retain the participation of illiquid juniors. Recall that when outside finance is possible, the junior dilution mechanism permits reorganization law to include a plan proposal by essential, though illiquid, holders of junior interests who will have a right to retain the equity interest in the reorganized debtor without negotiation between the juniors and any outside investor. The junior dilution mechanism causes the court to increase the interest payable on the bond obligations up to the point at which the demand for the bonds at a fixed price exceeds the senior claimants' supply. When junior claimants are illiquid and cannot afford to offer to buy all of the senior claims, the offers to purchase by third-party market participants will shut off the dilution. But the third parties help courts to value the firm by potentially displacing the senior claimants, not the junior claimants. ${ }^{118}$ Put simply, because our junior dilution mechanism only puts the senior claims on the trading block, effective market valuation is possible without separation of the reorganized firm's residual interest from those who may need to retain such junior interest. In contrast, Baird's auction proposal and Bebchuk's option proposal would require illiquid junior claimants to incur

118. Remember that in the junior dilution mechanism, third parties potentially offer to buy the debt of senior claimants if the interest rate on the debt exceeds the absolute priority inducing rate. 
the additional transaction costs of borrowing money (or the costs of bargaining with the new owners of the firm) so that the juniors could continue to provide their value-added management skills. ${ }^{119}$ Consequently, as a mechanism for external finance, the junior dilution mechanism is superior to those proposals that require juniors to buy the entire firm (or at least the senior claims) in order to retain their residual interest, because it can harness potential market liquidity without forcing the juniors to negotiate their continued participation in the reorganized firm.

We make this general claim even though we recognize that Roe's proposal could be tailored to allow junior retention of a debtor's equity interest while also avoiding negotiation or litigation over valuation. Because Roe proposes to sell only a slice of a debtor, the slice not sold could be reserved for essential juniors, provided that the sale proceeds justify a continued junior interest. (Moreover, if that slice were sold in separate components of the firm's new capital structure, relative valuations among those components would be possible.) Nevertheless, in at least two respects, Roe's proposal has deficiencies not shared by our dilution mechanism.

First, either the price of the slice to be sold would be importantly vulnerable to strategic manipulation, or that slice would importantly restrict the distribution of ownership in the reorganized debtor. To elaborate, if under Roe's proposal, a small, say ten percent, vertical slice of the debtor were sold to accomplish valuation, the lion's share of interest in the firm would be available for distribution to the former junior interests (and, for example, if desirable, a sizeable share of new debt would be available to be concentrated in the hands of a particular former creditor who could continue as an effective monitor). But when such a small slice went up for auction, the price would be subject to improper influence, up or down, through manipulative buy bids by juniors and manipulative sell offers by seniors, each hoping to establish an artificial value favorable to its stake in the portion of the debtor not sold. To combat such manipulation, one could make that strategy expensive by increasing the size of the slice. ${ }^{120}$ But such an increase would limit the flexibility a court would have to concentrate

119. One might question whether the juniors' transaction costs of borrowing would be substantial in a thick market where, by hypothesis, information about the debtor is available to third parties. We do not contend that such costs would be as great as in a thin market, where borrower and lender might be locked in a bilateral negotiation. But even thick markets vary in their degrees of thickness, and information is never entirely free. Under our junior dilution mechanism, the market needs to value only a piece of the debtor-a debt obligation in our illustrations. In an auction of the entire debtor, the market (including any lender to the junior interest) would have to evaluate the entire firm. It may be less expensive to evaluate a fixed debt obligation than to evaluate the entire firm. Cf. Stewart C. Myers, The Capital Structure Puzzle, 39 J. FIN. RES. 575, 581-85 (1984) (describing the "pecking-order" theory of corporate finance).

120. Such manipulation would likely be fraudulent under both state and federal law. As the positive rate of crime attests, however, legal prohibitions do not deter all undesirable activity. 
new equity (or new debt) in the hands of particular investors. Further renegotiation would be necessary to place the interest sold in the proper hands, and thus, in this respect, the Roe proposal would face the same problem as the Baird and Bebchuk proposals. The junior dilution mechanism, in contrast, can reserve new equity for the junior interest, yet at the same time sell the entire senior interest, the price of which would be maximally expensive to manipulate.

Second, once one takes into account the premium associated with a controlling interest in a firm, the Roe proposal may systematically undercompensate junior interests and overcompensate senior interests. Assume, for example, that the debtor in the current illustration is in fact worth $\$ 110$, but that $\$ 20$ of this value is attributable to cash flows that the controlling shareholder of the debtor can convert to its own use to the extent such flows are not needed for debt service. ${ }^{21}$ Absolute priority dictates that the senior interest, owed $\$ 100$, receive all but $\$ 10$ of the debtor's value, the remainder to the juniors. If the Roe slice is small, however, it might not reflect any of the $\$ 20$ control premium, and the entire firm might be distributed to the seniors. ${ }^{122}$ The dilution mechanism, in contrast, permits outside investors to account for the control premium in the valuation of the senior interest, even though that senior interest will include no part of the new equity interest, which is already in place in the hands of the old junior interest. ${ }^{123}$ In this illustration, the junior interest could hold the debtor's entire new equity with new debt offered to the senior interest. If the debtor is truly worth $\$ 110$, as the juniors contend and as is assumed here, the dilution mechanism could be employed and would establish an equilibrium interest rate for the debt in the hands of seniors, with the juniors holding all new equity. That is, the mechanism would set the interest rate for debt to be held by the seniors such that this debt would be worth exactly $\$ 100,{ }^{124}$ and the dilution mechanism could thus preserve absolute priority

121. A principal function of debt is to prevent diversion of cash flow by those in control of a firm. See, e.g., Michael C. Jensen, Agency Costs of Free Cash Flow, Corporate Finance, and Takeovers, 76 AM. ECON. REV. 323, 324 (1986) (propounding the "control hypothesis" of debt creation).

122. This problem could be remedied if the slice were large enough to constitute control, but then, as discussed above, the bankruptcy court would lack the flexibility to concentrate control in the pre-bankruptcy juniors, as might be efficient.

123. Note that where external markets are viable, the control premium will reside somewhere within the junior interest even if that interest is atomized and no junior can afford to bid for any of the debt issued to the seniors.

124. In theory, a modified version of Roe's proposal could replicate this result. As noted, supra note 121 , debt serves to prevent diversion of cash flow by those in control of a firm. Thus, in this illustration, if the slice sold were of a capital structure that included $\$ 100$ in debt and the remainder equity, the Roe-perceived value of the firm might accurately include $\$ 100$ for the debt portion alone, leaving the entire residual value--though unrevealed by the sale of a small, noncontrol slice-properly in the hands of the juniors. This would be true, however, only if the interest rate on the debt were set at $I_{A P}$, as that term is defined in Section V.A above (by reference to $D_{A P}$ in Part III above). And while the dilution mechanism would reveal $I_{A P}$, a court or other 
even in the face of a control premium that would not necessarily be reflected in the sale of a slice. ${ }^{125}$

\section{B. Thin External Markets}

Now consider the case in which the junior interest is illiquid and external finance is unavailable or imperfectly available. This might be so for medium or small firms, about which there is little easily verifiable information. In such a case, it is straightforward to see that none of the other market-based reform proposals provides a satisfactory result. Each of the Baird, Roe, and Bebchuk proposals relies on an informed bidder, the junior interest, or an outsider to generate an offer that protects the juniors' residual interest in a reorganized firm whose value is greater than the senior claim. Under any of these proposed reforms, unmitigated junior illiquidity is simply dumb luck for the seniors, who can benefit through inaction by the juniors and have little incentive to do otherwise. The dilution mechanism, by contrast, requires action by seniors who want to realize their priority interest. This requirement for action can mitigate the problem of junior illiquidity and lead toward absolute priority in ways not possible under the alternative reform proposals.

This point can best be illustrated through a comparison of our senior dilution mechanism with the Bebchuk reform proposal. Specifically, it is useful to think of Bebchuk's proposal as a special case of our mechanism in which senior claimants are constrained to submit a bidding schedule in which they offer to sell all of their shares for all potential levels of dilution. Returning to the terminology we used above in our simplest model, ${ }^{126}$ Bebchuk constrains seniors to ask $S(D)=N_{s}$ for all $D$. This constraint by itself assures $D^{*}=0$, and that the amount sold will be $B^{*}=B\left(D^{*}=0\right)$. That is, because the Bebchuk proposal would deem all seniors to have offered all of their shares at zero dilution, no matter what the value of those shares, the juniors' demand at $D>0$ becomes irrelevant, as supply necessarily equals or exceeds demand even with no dilution, the condition that triggers the

administrator of Roe's proposal could only guess at this value. (Establishment of an arbitrarily high interest rate in an attempt to capture the firm's entire value in the debt would not, in practice, solve the valuation problem, as such a firm would almost certainly emerge from bankruptcy with an unstable capital structure that would require further reorganization and a repetition of the same issue.) In other words, Roe's mechanism could reliably incorporate debt as a solution to the control-premium problem only if one already knew the answer to the question the mechanism is designed to address.

125. More generally, the dilution mechanism, like the Baird and Bebchuk proposals, gives a purchaser the incentive to account in a bid decision for the debtor's entire value, whether from a controlling or minority interest. The Roe proposal, in contrast, could establish an equilibrium valuation for the firm that excluded a portion of the value that purchasers of the slice sold would not expect to realize.

126. See supra Section III.C. 
cessation of dilution. Consequently, the only hope for juniors to realize fully any legitimate interest they may have is to bid the required fixed price for all shares at no dilution. If juniors are illiquid, this will not occur. Instead, juniors will purchase whatever shares they can afford, and the remainder of the shares that juniors cannot buy will remain with, and constitute a windfall for, seniors, in violation of absolute priority. This is the result of the Bebchuk proposal.

Under our dilution mechanism, matters are not so simple for seniors. ${ }^{127}$ With the unconstrained senior dilution mechanism in place, for example, multiple seniors within a class have an incentive to free-ride on one another, not tendering their shares at low levels of dilution when those shares are worth more than the fixed price, each hoping that other seniors will tender the amount necessary to at least equal the junior demand and thus set the minimum possible dilution level, which would benefit the seniors' unsold shares. In a related point, we showed that leverage from dilution shares can increase the bids of illiquid juniors when external finance is available but imperfect. ${ }^{128}$ As a result, any attempt among seniors to free-ride could not merely scuttle the seniors' collective desire to establish a zero dilution level based on junior illiquidity, but could dissipate that illiquidity itself as dilution increased, perhaps triggering the end of dilution only at relatively high levels (though never above $D_{A P}$ ). ${ }^{129}$ This would more likely be the case if the senior dilution mechanism were altered, as we suggested, so that dilution would be set at the highest level at which demand for shares equaled supply, if any such equality existed. We also demonstrated, moreover, that the acquiescence effect could lead seniors to refrain from tendering shares even at low levels of dilution, even when the value of those shares would exceed the fixed purchase price, if acceptance of the consequently higher level of dilution would increase the value of the debtor, because that value is endogenous to the maintenance of junior control and would thus increase the value of the seniors' unsold shares.

None of these phenomena (which could occur under junior dilution as well) would be possible under the Bebchuk proposal, which fixes the number of shares the seniors must offer at the maximum amount allowable. This is not to say that mitigation of absolute priority breach could not occur under the option approach. For example, if senior creditors were

127. See supra Section IV.C.

128. While Bebchuk's mechanism does not allow juniors to leverage the value of dilution shares to ameliorate their potential illiquidity, either Bebchuk's or our mechanisms might send credible signals of value to lenders from the action of less liquidity-constrained actors. For example, Eric Talley pointed out to us that a claimant with intermediate priority might be able to signal the value of its claim by pointing to the willingness of less senior claimants to buy at particular levels of dilution.

129. We illustrated an example of this possibility in Figure 4, supra Subsection IV.C.2. 
sufficiently liquid, they could bid against one another for the purchase options of illiquid juniors, thus driving the juniors' return toward absolute priority much in the way that senior free-riding can drive juniors toward absolute priority under the dilution mechanism. But this result under the option approach, and not under the dilution mechanism, requires senior liquidity and affirmative action on the part of the seniors. Similarly, the benefits of acquiescence are always possible ex post as, by hypothesis, the continued participation of the juniors is wealth-maximizing, and nature favors Coasean bargains. Nevertheless, such a bargain could require negotiation expense unnecessary under the dilution mechanisms we propose. ${ }^{130}$ Unlike the dilution mechanism, the option approach itself does not facilitate senior strategic behavior. Indeed, for the same reason, no proposal that seeks to establish value through the sale of a fixed interest in the debtor can benefit from the artifices of strategic seller behavior, at least where the seller acts only as a seller.

\section{CONCLUSION}

Any suggestion for reform of the bankruptcy reorganization process must sail carefully past the economic versions of Scylla and Charybdis: thin markets and high transaction costs. Where markets are thick, information full, and transaction costs low, either markets or structured negotiation backed by judicial determination will allow a financially distressed firm to reorganize easily in a manner consistent with absolute priority. This said, where markets are not thick but thin, there is an understandable tendency to favor negotiation, or ultimately litigation, as under current American bankruptcy law. Negotiation and litigation, however, carry transaction costs, and the relatively uninformed estimate of a judge before interested parties may not accomplish absolute priority despite the imposition of these costs. ${ }^{131}$ Even where markets are thick, moreover, and can be relied on for valuation outside of the bankruptcy reorganization process, a use of markets that entails a sale of the debtor may require negotiations outside bankruptcy, between the purchasers and the former owners whose human capital may be specialized to the firm's operation. These negotiations, too, have costs.

The dilution mechanisms that we propose here attempt to navigate the safest course among these hazards. Like other proposals to employ market tests in valuation, the dilution idea relies on the incentives of sellers and buyers. Where external markets are thick, the junior dilution mechanism permits an accurate measure of value and, unlike alternative market

130. Cf. supra Section VI.A (discussing the possibility of this extra negotiation expense).

131. See supra text accompanying note 19. 
mechanisms, would do so without the sale of an interest in the debtor by those who may be essential to the debtor's successful continuation. Thus, value can be maintained, and absolute priority honored, at low transaction cost. Where external markets are thin, and holders of junior interests entitled to a distribution from an insolvent firm are illiquid, the dilution approach, like any market mechanism, will work imperfectly. ${ }^{132}$ But unlike other market mechanisms, which consign sellers to a passive role, dilution permits the greed of seniors, as sellers, to undermine the very strategic advantage the sellers seek from junior illiquidity. In any case, the costs of a negotiated or litigated bankruptcy reorganization process would be avoided.

To the extent that we have succeeded in proposing a way to accomplish a simple resolution of financial distress consistent with absolute priority, we have accomplished a great deal. As the Supreme Court recognized in its recent LaSalle opinion, ${ }^{133}$ absolute priority matters. When investors write contracts to establish various priorities, they presumably do so for a reason. The reason may well be that such priority engenders efficient incentives. Thus, when the law ignores a contractual priority arrangement, it upsets expectations and can undermine efficiency. Unfortunately, there are myriad examples of how current practice fails in this respect. Many believe that the bankruptcy reorganization process tends to overcompensate equity holders at the expense of unsecured creditors. In one study of large reorganizations, this proved to be true in numerous cases-including those of Braniff and Lionel, just to choose recognizable names. ${ }^{134}$

There is also a competing vision of the bankruptcy process, one in which senior creditors, who are seen as large and vigilant, take almost the entire value of a distressed firm regardless of their absolute priority desert. ${ }^{135}$ This view of bankruptcy law dates back to the railroad reorganizations that spawned modern corporate reorganizations. The famous Boyd case, ${ }^{136}$ a direct doctrinal ancestor of LaSalle, was such a case.

132. The possibility that markets are imperfect, combined with the imperfection in negotiation and litigation under current reorganization law, leaves room for the possibility that investors would prefer to forgo any sort of valuation in the face of a debtor's financial distress, preferring instead to rely on ex ante predictions about, and agreements on the disposition of, a troubled firm's value. See Adler, Corporate Insolvency, supra note 15; Adler, Financial and Political Theories, supra note 15; cf. Michael C. Jensen, Takeovers: Their Causes and Consequences, J. ECON. PERSPECTIVES, Winter 1988, at 21, 31-32 (recommending a uniformly divided capital structure to avoid conflicts over valuation in the event of financial distress); Schwartz, supra note 8, at 237-41 (describing renegotiation-proof ex ante contracts). We confine ourselves here, however, to a comparison among ex post approaches, leaving for another day a comparison between ex ante and ex post insolvency regimes.

133. Bank of Am. Nat'l Trust \& Sav. Ass'n v. 203 N. LaSalle St. P'ship, 526 U.S. 434 (1999).

134. See, e.g., Lynn M. LoPucki \& William C. Whitford, Bargaining over Equity's Share in the Bankruptcy Reorganization of Large, Publicly Held Companies, 139 U. PA. L. REV. 125, 14043 (1990).

135. See supra note 25 .

136. N. Pac. Ry. Co. v. Boyd, 228 U.S. 482 (1913). 
In LaSalle, the Supreme Court directed that bankruptcy judges reject current practice and resolve these competing conceptions in favor of a middle path centered on absolute priority. The dilution approaches we propose here are, we hope, a guide to that path. 